\title{
A Theoretical Research Framework of Future Sustainable Urban Freight Transport for Smart Cities
}

\author{
Zhangyuan $\mathrm{He}^{1,2, * \bullet}$ and Hans-Dietrich Haasis ${ }^{3}$ \\ 1 Chair of Maritime Business \& Logistics, University of Bremen, 28359 Bremen, Germany \\ 2 A Member of the International Graduate School for Dynamics in Logistics, University of Bremen, \\ 28359 Bremen, Germany \\ 3 Full Professor and Head of Chair in Maritime Business \& Logistics, University of Bremen, 28359 Bremen, \\ Germany; haasis@uni-bremen.de \\ * Correspondence: zhe@uni-bremen.de; Tel.: +49-174-8652437
}

Received: 1 February 2020; Accepted: 22 February 2020; Published: 5 March 2020

check for updates

\begin{abstract}
This paper aims to construct a theoretical research framework for sustainable urban freight transport (SUFT) from the perspectives of future urban development and distribution innovations, and appropriate research methods are discussed, as well. Urban freight transport plays a critical role in the promotion of sustainable and livable cities. According to the literature review, considerable research on SUFT has focused on resolving some specific problems with a short-term perspective. The existence of an urban freight transport strategy is noted, which should be embedded in an overall sustainable development strategy with a long-term perspective (approximately 20-30 years). Nevertheless, considerable research has paid scant attention to the long-term planning of SUFT. Given this, this paper contributes to the closure of this gap. First, this paper presents a systematic literature review (SLR) to highlight published papers involving foresight research within the past 16 years (2003-2018). This step contributes to the understanding of research methods that can be used in foresight research. Subsequently, this paper discusses the impacts of both urban development and distribution innovations on future SUFT, and these effects are used to select the appropriate methods to construct the theoretical research framework. Finally, the theoretical research framework of long-term planning for SUFT is developed on the basis of two future perspectives: the trends of urban development and the application of urban distribution innovations. This framework is intended to provide an approach to designing sustainable urban logistics, taking into account urban development and distribution innovations.
\end{abstract}

Keywords: sustainable urban freight transport; sustainable city logistics; sustainability; foresight research; theoretical research framework; future perspective; urban development; distribution innovations

\section{Introduction}

Economic growth necessitates flexible transportation to ease access to resources and trade markets [1]. Transportation is the main concept for promoting social intelligence approaches and economic development [2]. Urban freight transport (UFT) has been defined as a process and a system to collect, transport, and distribute goods within urban areas. Although urban freight activities have continually contributed to the economic growth of cities, they have caused the majority of environmental externalities within urban areas. These negative externalities primarily consist of air pollution, congestion, noise, etc. [3,4]. Therefore, considerable research has focused on promoting sustainable urban freight transport (SUFT), which is commonly based on the conventional urban freight network. The dimensions of sustainability primarily include economic (e.g., economic performance), 
environmental (e.g., emissions, transport), and social aspects (e.g., public policy, customer privacy) [5]. A conventional urban freight network generally consists of two types: single-tier and two-tier (as depicted by Figure 1). The former system is commonly used in small or medium-sized cities, and the two-tier system is more suitable for large/megacities [6,7]. However, city development has brought challenges to the conventional network structure of UFT, particularly for large/megacities around the world. For example, urban population growth has increased the commodity demands and freight flows, and urban sprawl has increased the delivery range. It is noted that considerable research has paid little attention to the connections between freight transport and urban development [8]. This result reveals that the research on SUFT lacks systematic consideration of city development from a long-term view. Indeed, an urban freight transport strategy should be embedded in an overall sustainable development strategy with a long-term perspective (approximately 20-30 years) [9]. Therefore, it is critical to the comprehensive consideration of city development and sustainable urban freight planning from a long-term view.
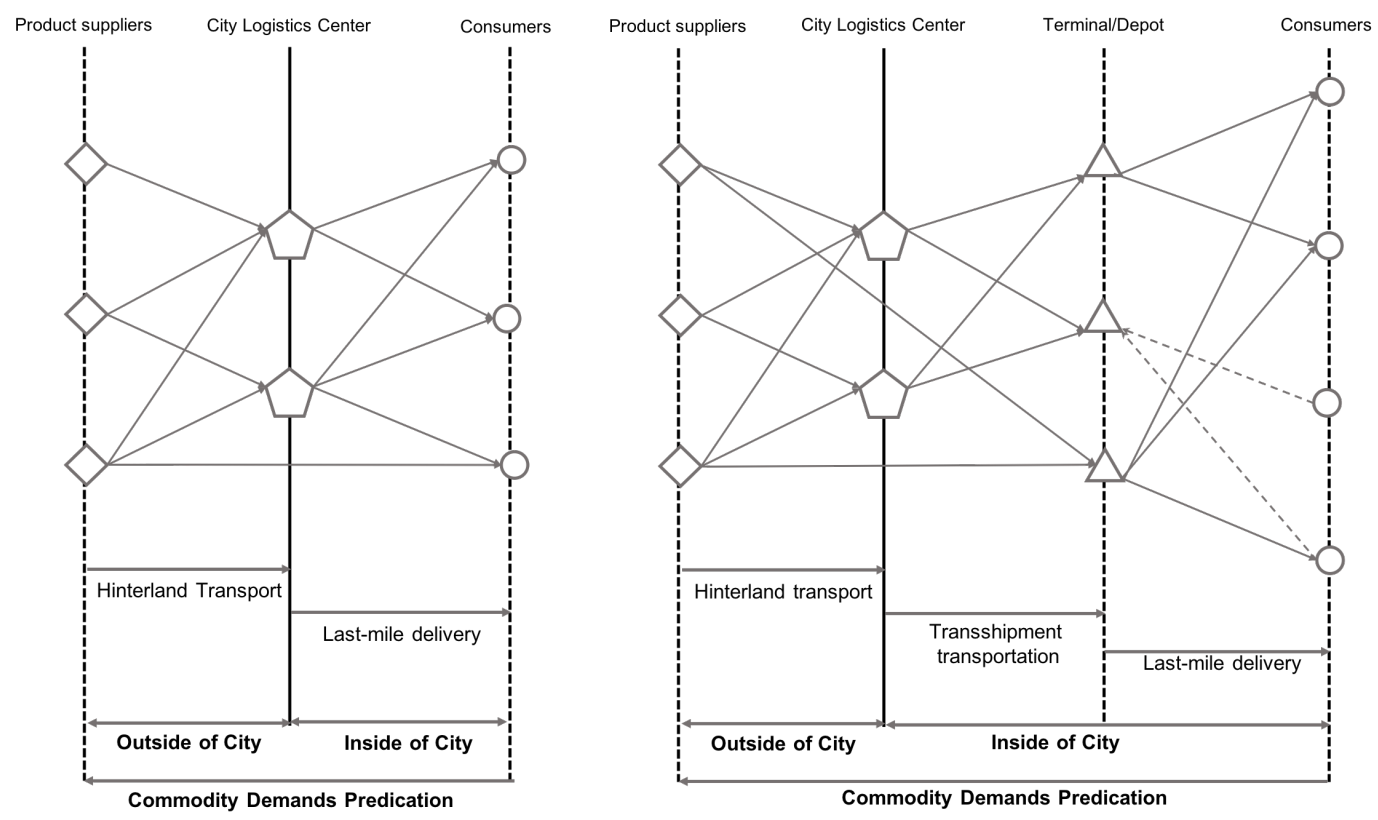

Figure 1. Single tier and two tiers of the urban freight system (Based on $[7,10]$ ).

In recent years, the concept of the "smart city" has increasingly become a popular topic in the academic field. This concept has arisen as a solution for improving the sustainability and livability of cities through the effective urban management of governance, energy, and transportation [11,12]. Since 2018, some research has focused on the topic of sustainable transport for smart cities, which primarily surround smart mobility. For example, Al-Thani et al. (2018) [13] adopted the Delphi approach to investigate the influences of both advanced transport and communication technologies on the future sustainability of the city of Doha and its neighborhoods. Freudendal-Pedersen et al. (2019) [14] discussed the impacts of mobility on smart cities, particularly on the aspects of automation and sustainability. Tobey et al. (2019) [15] demonstrated a conceptual framework for planning smart communities to take account of sustainable transport, which employed an iterative three-phase development loop. Hammad et al. (2019) [11] proposed a mathematical optimization framework to optimize zoning, land-use allocation, the location of novel constructions, and investment decision-making related to infrastructure projects in smart cities. This framework is able to connect to other platforms in a city setting. Bamwesigye and Hlavackova (2019) [2] discussed the global heterogeneous characteristics of both sustainable transport and smart cities. Behrendt (2019) [16] indicated that the vast majority of European policy discussions on the topic of smart cities revolve around cars (including autonomous cars and smart vehicles), while cycling is rarely considered. From 
this result, he made policy suggestions for addressing these issues and for future research. These works have widely discussed the application of innovative sustainable transport modes in future smart cities. However, much less research has paid attention to the impacts of these innovative transport modes on future sustainable urban freight transport. Additionally, these papers specifically focused on the notion of smart cities based on information and communications technology (ICT) or the internet of things (IoT), whereas the physical urban perspective was barely considered. For example, urban population growth causes urban sprawl to increase the distribution range and delivery frequency. Although the application of these innovative transport modes can reduce the negative environmental impacts of freight movements, this gap restricts the sustainability of future SUFT in economic and social aspects. Given that, this paper specifically focuses on the physical perspective of urban development and the distribution innovations for smart cities.

The trends of urban development are exogenous trends that have exacerbated the challenges of the urban freight system. To respond to these challenges, urban logistics providers have devoted efforts to finding appropriate endogenous solutions to promote sustainability, effectiveness, and security. The usage of emerging transport modes is an efficient solution for logistics providers. An example is the utilization of electric vehicles (EVs) to deliver goods to customers within urban areas, which can reduce air pollution. Notwithstanding this, various distribution innovations operate together as a system that radically influences the conventional urban freight network [17]. For example, using urban freight trams requires the building of several transit stations and the integration of the passenger and freight. Although considerable research has paid more attention to the usage of one or two distribution innovations in the urban freight system, they have focused on short-term planning (approximately 5-10 years). This observation implies that comprehensive consideration of the integration of urban distribution innovations and their impacts on the conventional urban freight network is lacking. Additionally, several technology companies have launched projects involving future urban freight vehicles. An example is the concept of "Future urban freight mobility" proposed by Volkswagen (Germany) in 2018; this vehicle integrates the mobile depot, robotic vehicle, and delivery robots. From sustainable transition perspectives, these projects are "new technologies typically link to the old technology in the form of an auxiliary add-on, often to improve its functioning" [18]. From the view of futurology, this finding implies that using urban distribution innovations in the conventional urban freight system is a possible barrier to the flexibility and sustainability of UFT. Therefore, foresight research that combines urban distribution innovations and urban freight network planning is also necessary.

In sum, both exogenous (city development) and endogenous (distribution innovations) trends of UFT have exacerbated the challenges of the conventional urban freight network from a long-term perspective. Therefore, foresight research on SUFT contributes to the sustainable transition of city logistics, thereby promoting sustainable and livable cities in the future. Reviewing published papers on city logistics indicates that considerable research has focused on addressing specific problems in the short-term. This finding reveals that much research has hardly employed foresight methods to investigate future sustainable urban freight transport. Applying foresight research methods is an efficient solution for researching sustainable urban logistics from exogenous and endogenous tendencies. To this end, the SLR of foresight research contributes to the understanding of the state-of-the-art in foresight research and the selection of appropriate methods for future sustainable urban freight transport. To fill these gaps, we adopted the SLR approach to find articles on foresight research that have been published in the past sixteen years (2003-2018). From the findings in the previous step, the overview approach was used to assess the impacts of urban development and distribution innovations on the future sustainable urban freight system, and these effects were used to select the appropriate methods of foresight research to construct a theoretical framework. Meanwhile, we followed the general framework of foresight research to improve the theoretical framework that is proposed in this paper. 


\section{Research Questions and Methodology}

From the previous discussion, we determined that the long-term planning of sustainable urban freight transport or relevant foresight research is lacking. Additionally, the research on urban freight network design has paid scant attention to the trends of both urban development and the integrated application of distribution innovations. This result highlights the fact that considerable research has paid little attention to the long-term planning of sustainable urban logistics, as well as the impacts of these two trends for the UFT. At present, to the best of our knowledge, such studies are absent. Unmistakably, the comprehensive consideration of these two trends in the design of the urban freight network can further promote the sustainability and flexibility of the future urban freight system. To this end, this paper aims to develop a theoretical framework of foresight research on SUFT to resolve this gap. Consequently, the research questions (RQ) of this paper are presented as follows:

RQ 1. What is the state-of-the-art in foresight research, and which methods are suitable for researching future sustainable urban freight transport?

RQ 2. What are the exogenous and endogenous trends of SUFT?

RQ 3. How can appropriate methods be selected for the long-term planning of SUFT?

RQ 4. How should the long-term planning of sustainable urban freight transport be conducted from future perspectives?

To answer the above research questions, we followed the research methodology design depicted in Figure 2. First, we used the SLR approach to determine articles involving foresight research published in the period of 2003-1018 on Scopus. The intention of this step was to understand the state-of-the-art of foresight research and determine the research methods used in the articles. Subsequently, the impacts of both urban development and distribution innovations on urban freight transport were assessed. Following this analysis, we selected the appropriate research methods for the long-term planning of SUFT. Finally, the theoretical research framework was proposed on the basis of the previous steps.

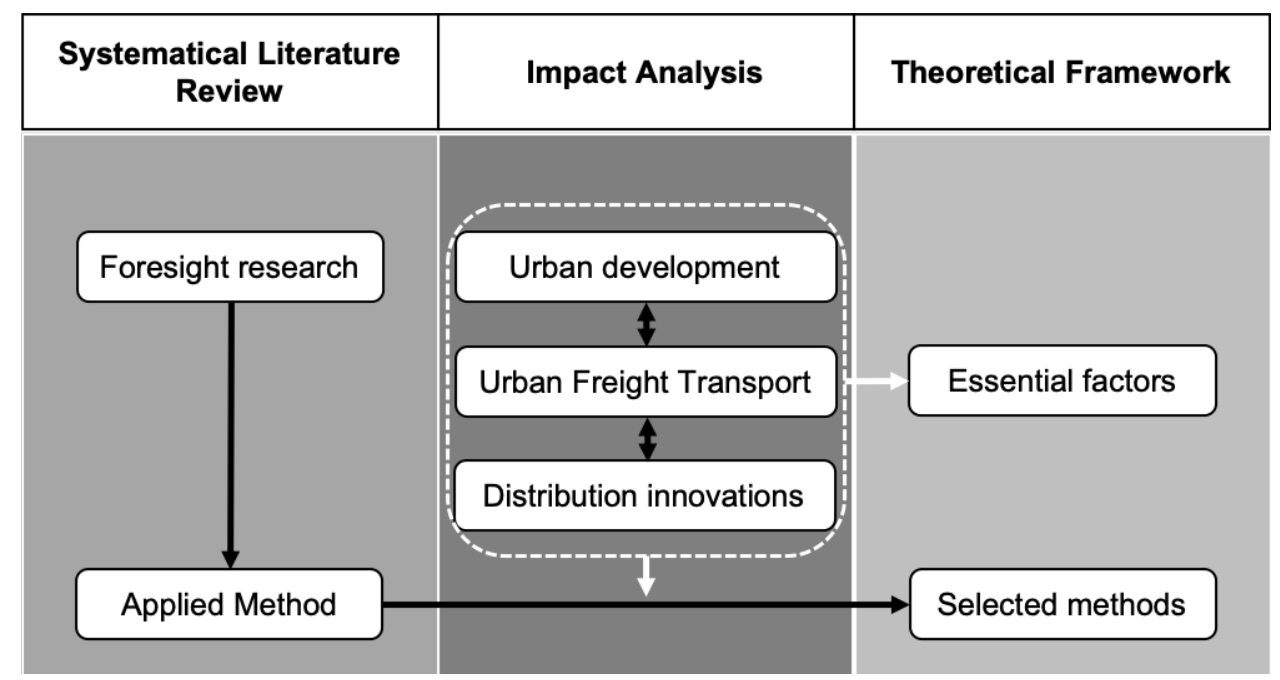

Figure 2. Research methodology (Source: Authors' own elaboration).

\section{Literature Review of Foresight Research}

To respond to RQ 1, we employed a systematic literature review (SLR) to find research articles that have been published in the past sixteen years (2003-2018). As presented in Table 1, the keyword is only one term: foresight research. The purpose was to understand which academic field has used the approach of foresight research as well as to determine the applied methods in these articles. Ultimately, 58 papers matched this objective. 
Table 1. Paper selection.

\begin{tabular}{cc}
\hline Items & Description \\
\hline Main Keywords & Foresight research \\
Language & English \\
Document types & Journal Articles, Conference Papers, Book Chapters \\
Source & Scopus \\
Time interval & $2003-2018$ \\
\hline
\end{tabular}

\subsection{Descriptive Analysis of Papers}

As presented in Figure 3, the peak in the number of papers was in 2017 when 14 articles covered foresight research on the distinct academic field. Despite the fluctuation in 2018, it is possible to appreciate the stable increase in the contributions related to foresight research in the last sixteen years. Of these 58 articles, eleven papers were published in the journal Foresight.

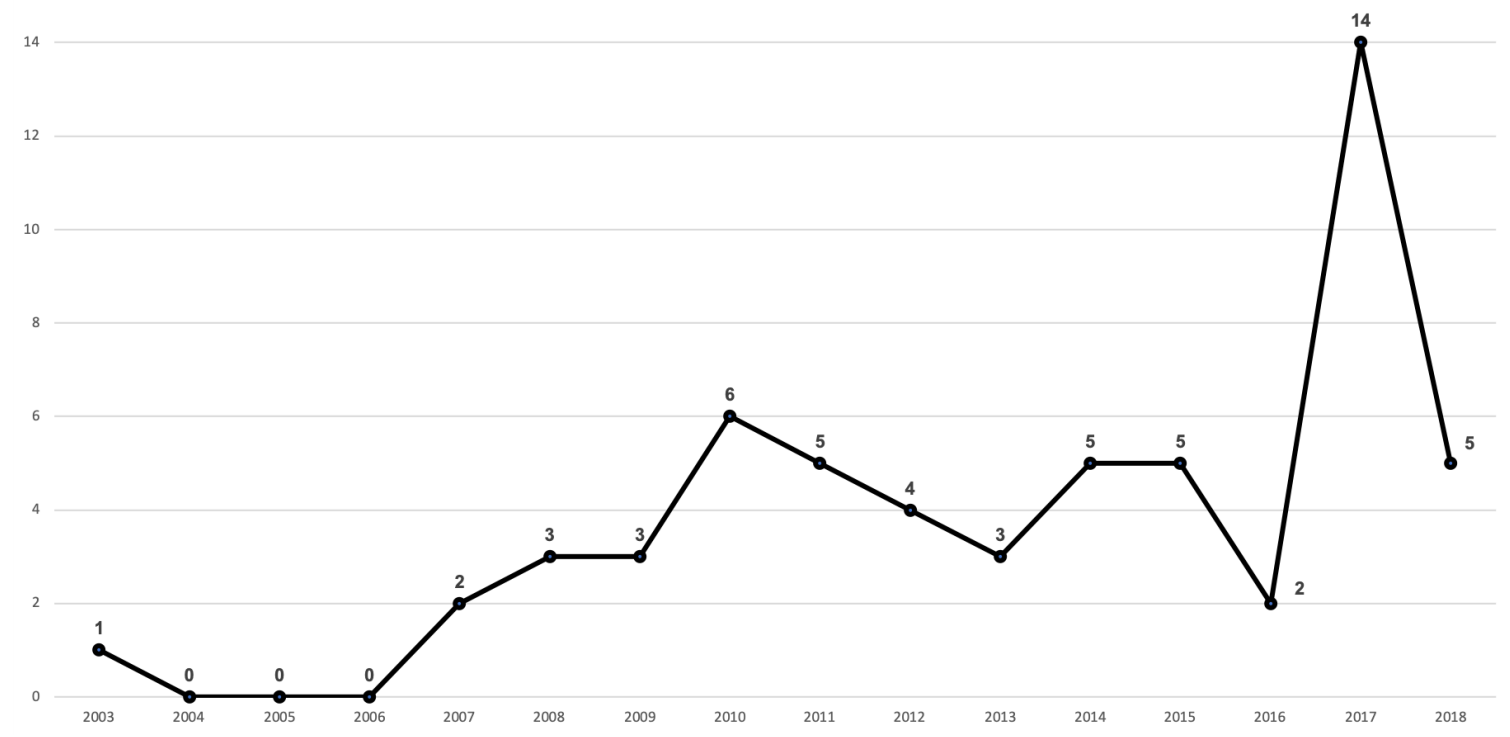

Figure 3. Number of academic publications on foresight research.

To meet the purpose of the literature review, as mentioned previously, we classified this corpus by the subject area of these 58 papers. This study employed Scopus's analysis system of the search results. The literature has mainly covered 11 subject areas. Of these subject areas, Others consist of Biochemistry, Genetics \& Molecular Biology, Earth E Planetary Sciences, Environmental Science, as well as Materials Science.

As presented in Figure 4, the subject area of Business, Management and Accounting accounted for $26.7 \%$ of the article corpus. There were 28 papers in this field. The subjects Engineering, Economics, Econometrics and Finance, and Social Science accounted for $10.5 \%$ each. This finding highlights that foresight research has received more attention in these subject areas, particularly in Business, Management and Accounting. 


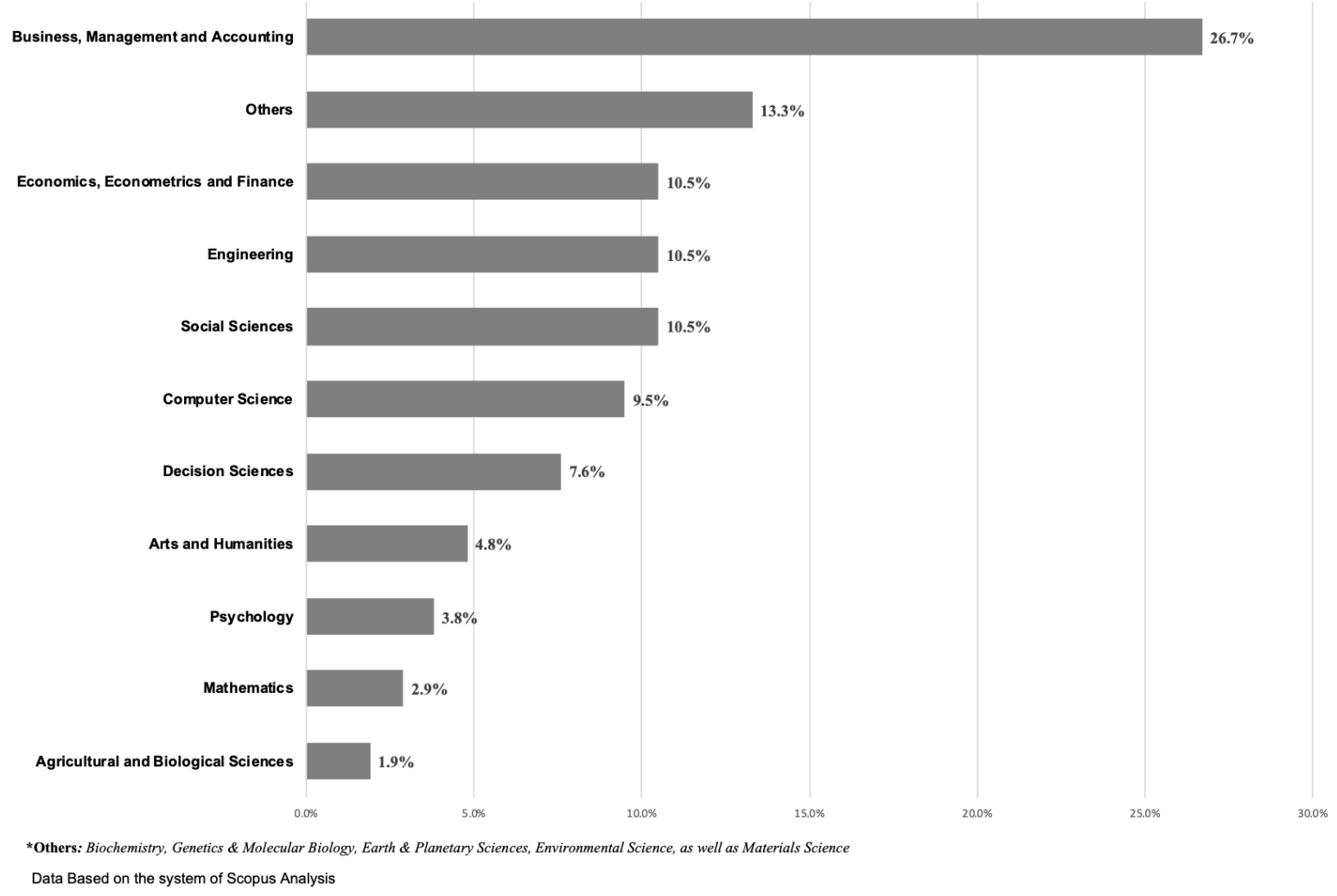

Figure 4. Subject areas of academic publications on foresight research.

\subsection{Analysis of Papers on Foresight Research}

Following the classification of subject areas, the keywords of the article corpus were determined and analyzed. As indicated in Table 2, the topic "Technological innovations" covered ten subject areas. An example is the research paper of Shostak et al. (2017) [19], which covered six subject areas. This high rate of coverage implies that this topic is a popular field in foresight research. This finding also reveals that distribution innovations need to be systematically estimated in foresight research on SUFT. Additionally, there were 22 articles related to the topic "Technological innovations". Nevertheless, only three articles were involved in the topic "Transport \& Supply chains". In these three research papers, Fiorini and Lin (2015) [20] analyzed the application of foresight studies in the transport sector, and their aim was to present good practices and the potential benefits of using foresight studies in the transport sector. Furthermore, the research of Strzelczak (2015) [21] discussed possible novel ontology-aided solutions for managing manufacturing and logistics operations as a result of foresight research on industries. Strzelczak (2017) [22] investigated feasible functional arrangements of production internet by reflecting on the state-of-the-art, supplemented by foresight research. This finding reveals that, thus far, foresight research on urban freight planning is lacking, as this analysis did not find evidence of literature reviews regarding foresight research on urban logistics.

Given that urban development and distribution innovations radically exacerbate the challenges of urban logistics, long-term planning of urban freight transport is capable of further promoting sustainable and livable cities. Before the discussion of critical factors in future urban logistics planning, foresight research methods need to be determined. Given this requirement, the applied methods in the article corpus were determined and analyzed. 
Table 2. Topics of the groups of papers on foresight research and their subject areas.

\begin{tabular}{|c|c|c|c|c|c|c|c|c|c|c|c|c|c|}
\hline \multirow[b]{2}{*}{ Topic } & \multirow[b]{2}{*}{ Description } & \multirow[b]{2}{*}{ Papers } & \multicolumn{11}{|c|}{ Subject Area } \\
\hline & & & $\begin{array}{l}\text { Business, } \\
\text { Management \& } \\
\text { Accounting }\end{array}$ & Engineering & $\begin{array}{l}\text { Economics, } \\
\text { Econometrics \& } \\
\text { Finance }\end{array}$ & $\begin{array}{c}\text { Social } \\
\text { Sciences }\end{array}$ & $\begin{array}{l}\text { Computer } \\
\text { Science }\end{array}$ & $\begin{array}{l}\text { Decision } \\
\text { Sciences }\end{array}$ & Psychology & $\begin{array}{c}\text { Arts \& } \\
\text { Humanities }\end{array}$ & Mathematics & $\begin{array}{l}\text { Agricultural } \\
\text { \& Biological } \\
\text { Sciences }\end{array}$ & Other \\
\hline $\begin{array}{l}\text { Technological } \\
\text { innovations }\end{array}$ & $\begin{array}{l}\text { Foresight research on emerging technologies } \\
\text { (e.g., information and communications technology, } \\
\text { digitalization) and their impact analysis }\end{array}$ & {$[19,23-43]$} & $\checkmark$ & $\checkmark$ & $\checkmark$ & $\checkmark$ & $\checkmark$ & $\checkmark$ & & $\checkmark$ & $\checkmark$ & $\checkmark$ & $\checkmark$ \\
\hline $\begin{array}{l}\text { Company } \\
\text { development }\end{array}$ & $\begin{array}{l}\text { Foresight research on company development } \\
\text { and applied framework }\end{array}$ & {$[44-48]$} & $\checkmark$ & $\checkmark$ & $\checkmark$ & & & & $\checkmark$ & & & & \\
\hline $\begin{array}{l}\text { Uncertainty } \\
\text { analysis }\end{array}$ & $\begin{array}{l}\text { Integrating the concept of uncertainty into foresight } \\
\text { research }\end{array}$ & {$[49,50]$} & $\checkmark$ & $\checkmark$ & $\checkmark$ & $\checkmark$ & & & & & & & \\
\hline $\begin{array}{l}\text { Strategic/ } \\
\text { Policy-making }\end{array}$ & $\begin{array}{l}\text { Using the theory of foresight research to develop } \\
\text { future strategies/policy }\end{array}$ & [51-56] & $\checkmark$ & & $\checkmark$ & $\checkmark$ & & $\checkmark$ & & & & & $\checkmark$ \\
\hline $\begin{array}{l}\text { Management } \\
\text { innovation }\end{array}$ & $\begin{array}{l}\text { Using the theory of foresight research to develop } \\
\text { innovative masures of management }\end{array}$ & [57-59] & $\checkmark$ & $\checkmark$ & & & $\checkmark$ & & & & $\checkmark$ & & \\
\hline $\begin{array}{l}\text { Methodological } \\
\text { research }\end{array}$ & Developing foresight research methods & {$[60,61]$} & $\checkmark$ & & & & & & $\checkmark$ & & & $\checkmark$ & $\checkmark$ \\
\hline Energy & Foresight research on energy (marketing) & {$[62,63]$} & $\checkmark$ & $\checkmark$ & & & & & & & & & $\checkmark$ \\
\hline $\begin{array}{l}\text { Transport \& Supply } \\
\text { chains }\end{array}$ & $\begin{array}{l}\text { Foresight research in the field of transport, logistics, } \\
\text { and supply chain management }\end{array}$ & [20-22] & & $\checkmark$ & & & & $\checkmark$ & & & & & \\
\hline Financial systems & $\begin{array}{l}\text { Foresight research on the financial and economic } \\
\text { system }\end{array}$ & [64] & & & $\checkmark$ & & & $\checkmark$ & & & & & \\
\hline $\begin{array}{l}\text { Marketing } \\
\text { management }\end{array}$ & $\begin{array}{l}\text { Foresight research on marketing management in } \\
\text { different sizes of enterprises }\end{array}$ & {$[65,66]$} & $\checkmark$ & $\checkmark$ & & & $\sqrt{ }$ & & & & & & \\
\hline $\begin{array}{l}\text { Psychological } \\
\text { Science }\end{array}$ & $\begin{array}{l}\text { Foresight research on psychology knowledge and } \\
\text { practice }\end{array}$ & {$[67,68]$} & $\checkmark$ & & $\checkmark$ & & & $\sqrt{ }$ & $\checkmark$ & & & & \\
\hline $\begin{array}{l}\text { Demographic } \\
\text { change }\end{array}$ & Foresight research on demographic change & [69] & & $\sqrt{ }$ & & & & & & $\checkmark$ & & & \\
\hline Others & $\begin{array}{l}\text { It includes social network analysis, methods of } \\
\text { foresight research, agriculture, and knowledge } \\
\text { management }\end{array}$ & {$[70-75]$} & $\checkmark$ & & & $\checkmark$ & $\checkmark$ & & & & & & \\
\hline
\end{tabular}




\subsection{Main Research Method Applied in the Article Corpus}

After reading the full papers, the main applied methods in the article corpus were identified. These research approaches consisted of literature review/overview, survey/interview, roadmapping/technology roadmapping, Delphi, scenario, trend exploration, workshops/brainstorming, bibliometrics, and SWOT (strengths, weaknesses, opportunities and threats). The definition of these nine methods are presented as follows:

- Literature review/Overview is a general method. The papers are commonly structured around related topics and use a discursive writing style.

- Survey/Interview refers to the investigation of specific groups of people using pre-set questions. The purpose is to gather the knowledge of interviewees.

- Roadmapping/Technology roadmapping is a method that outlines the future field and generates a timeline. Related factors include technologies, regulatory aspects, and market structures.

- Delphi is "a method that involves repeated polling of the same individuals, feeding back (occasionally) anonymized responses from earlier rounds of polling, with the idea that this will allow for better judgments to be made without undue influence from forceful or high-status advocates" [76].

- Scenario involves constructing a systematic and internally consistent vision associated with the future.

- Trend exploration is a method of forecasting future trends under the assumption that the future is a continuation of the past.

- Workshops/Brainstorming is "A creative and interactive method used in face-to-face and online group working sessions to generate new ideas around a specific area of interest" [76].

- Bibliometrics is a method based on a quantitative and statistical analysis of publications.

- $\quad$ SWOT is "a method which first identifies factors internal to the organization or geopolitical unit in question and classifies them in terms of strengths and weaknesses. It similarly examines and classifies external factors (broader socio-economic and environmental changes, for example, or the behavior of competitors, neighboring regions, etc.) and presents them in terms of opportunities and threats" [76].

The resulting classification of the article corpus is reported in Figure 5, where each paper can employ more than one research method. As expected, the literature review/overview is the primary applied methodology in the article corpus. Only one paper adopted a SWOT analysis. In these papers, the maximum number of methods per paper is two. For example, the research of Fiorini and Lin (2015) [20] employed the literature review/overview and scenario approaches; Lee et al. (2008) [74] adopted the methods of literature review/overview and trend exploration. This finding implies that a mixture of methods is used as a general approach in foresight research. Thus, the applied methods in the article corpus need to be further classified and analyzed.

Table 3 presents the results of connecting the research methods with the topics covered in each paper. The literature review/overview approach was widely used in the methods mix. Although most papers did not mention the literature review/overview method, this method was commonly used for fundamental descriptions (e.g., [29,32,40]). In addition, other methods mix were also applied in the article corpus. An example is Mendoncca et al. (2009) [50], who adopted the Delphi and scenario analysis methods. This finding reveals that the methods mix is an efficient solution for foresight research. Hence, foresight research on sustainable urban freight transport also needs to comprehensively consider the feasibility of the distinct methods mix. 


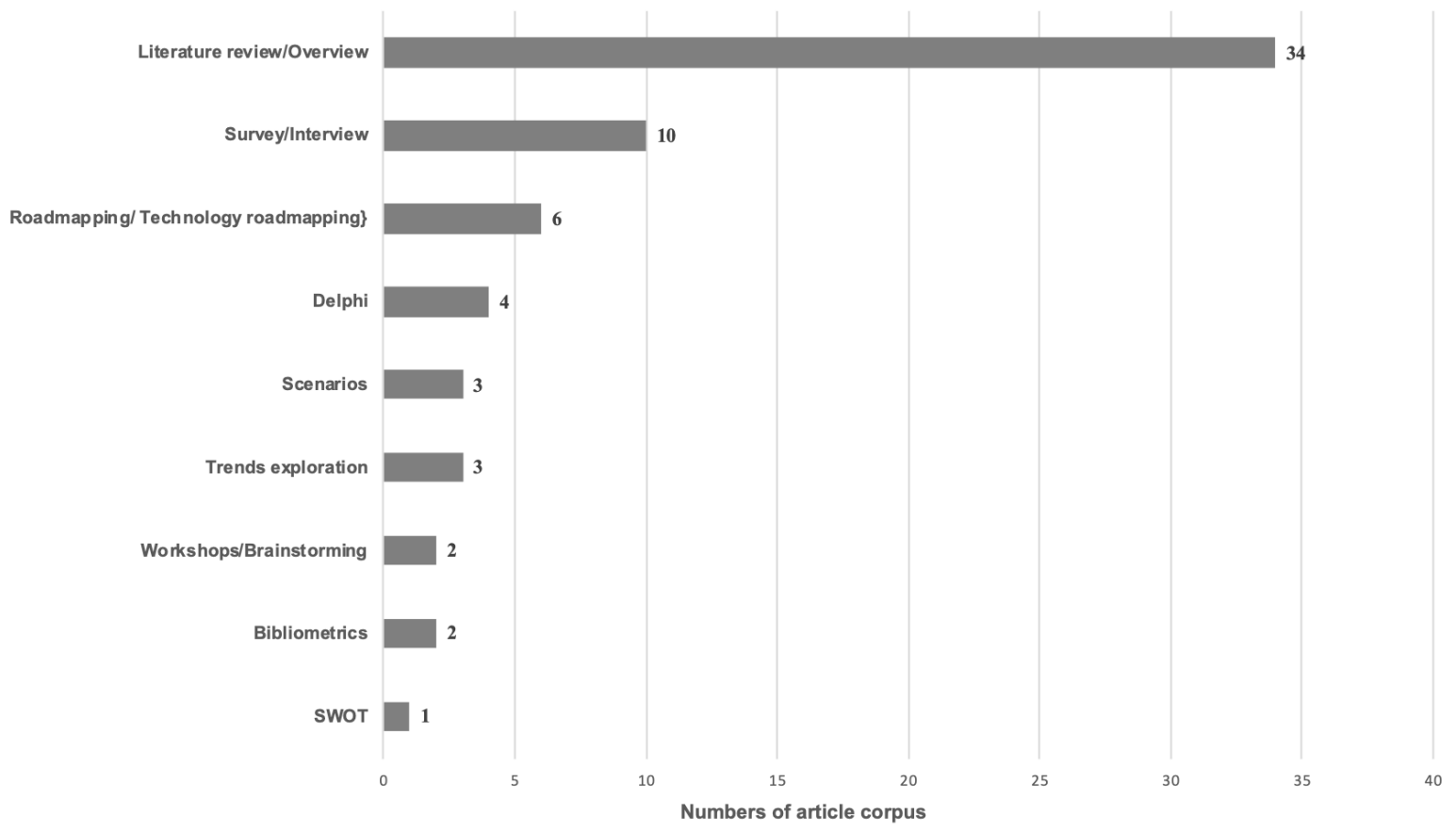

Figure 5. Types of research methods in the corpus.

According to the preliminary discussion, these nine methods are unable to develop a foresight research framework for future sustainable urban freight transport on the basis of the dimensions of urban development and distribution innovations. Although the literature review and trend exploration approaches seem to be suitable methods, there is a lack of methods to develop an operational strategy and network structure for future sustainable urban freight transport. Given this gap, it essential to integrate the other methods of foresight research into further analysis. Besides the above nine methods that can be used in foresight research, 25 methods are commonly employed in this field. The research of Popper (2018) [76] systematically discussed method selection for foresight research. In order to select the appropriate methods for developing the foresight research framework of sustainable urban freight transport, it is essential to systematically discuss the critical impact-factors of future sustainable urban freight transport. The first step is to understand the applied frequency of these 25 foresight methods, as well as the feasibility of their combination. 
Table 3. Topics and applied methods in the corpus.

\begin{tabular}{|c|c|c|c|c|c|c|c|c|c|}
\hline & Literature Review/Overview & Survey/Interview & Delphi & Scenarios & Trends Exploration & Workshops/Brainstorming & $\begin{array}{c}\text { Roadmapping/ } \\
\text { Technology Roadmapping }\end{array}$ & SWOT & Bibliometrics \\
\hline $\begin{array}{l}\text { Technology } \\
\text { innovations }\end{array}$ & {$[24-28,30,31,34-38,41-43]$} & {$[29,40]$} & - & - & - & {$[30]$} & {$[23,33,39]$} & - & {$[19,32]$} \\
\hline $\begin{array}{c}\text { Company } \\
\text { development }\end{array}$ & {$[44,46-48]$} & [45] & - & - & - & - & - & - & - \\
\hline $\begin{array}{l}\text { Uncertainty } \\
\text { analysis }\end{array}$ & [49] & - & [50] & {$[50]$} & - & - & - & - & - \\
\hline $\begin{array}{c}\text { Strategic/ } \\
\text { Policy-making }\end{array}$ & {$[51,52,56]$} & {$[54]$} & [53] & - & - & - & [55] & - & - \\
\hline $\begin{array}{l}\text { Management } \\
\text { innovation }\end{array}$ & {$[58,59]$} & - & - & - & - & - & [57] & - & - \\
\hline $\begin{array}{l}\text { Methodological } \\
\text { research }\end{array}$ & & [60] & {$[60,61]$} & - & - & - & - & - & - \\
\hline Energy & - & - & - & - & {$[62,63]$} & - & - & - & [62] \\
\hline $\begin{array}{l}\text { Transport \& } \\
\text { Supply chains }\end{array}$ & {$[20,22]$} & {$[21,22]$} & - & {$[20]$} & - & & [21] & & \\
\hline $\begin{array}{l}\text { Financial } \\
\text { systems }\end{array}$ & [64] & - & - & - & - & - & - & - & - \\
\hline $\begin{array}{l}\text { Marketing } \\
\text { management }\end{array}$ & - & [65] & - & - & - & - & - & [66] & - \\
\hline $\begin{array}{l}\text { Psychological } \\
\text { Science }\end{array}$ & {$[67,68]$} & - & - & - & - & - & - & - & - \\
\hline $\begin{array}{l}\text { Demographic } \\
\text { change }\end{array}$ & - & - & - & [69] & - & - & - & - & - \\
\hline Others & {$[71,72,74,75]$} & {$[70,73]$} & - & - & [74] & [70] & - & - & - \\
\hline
\end{tabular}




\section{Exogenous and Endogenous Trends of SUFT}

Section 3 demonstrates that considerable research has paid less attention to the long-term planning of sustainable urban freight transport. To respond to RQ 2, it is essential to understand the future trends of sustainable urban freight transport. As mentioned previously, the city and freight maintain a set of core relations [77]. However, a considerable body of research has paid scant attention to the links between urban development and city logistics planning [8]. Therefore, the future trends of urban development are an external factor of sustainable urban freight transport, and they are defined as exogenous trends of SUFT. Exogenous trends have exacerbated the challenges of sustainable city logistics. For example, urban population growth has motivated logistics providers to increase their delivery frequency within urban areas, which has caused traffic congestion and exacerbated land-use conflicts. To this end, urban logistics providers have employed or launched emerging transport modes to decrease environmental externalities to promote the sustainability of urban logistics; such modes include electric vehicles, delivery drones, and parcel lockers. This observation highlights that conventional urban freight transport has increasingly transformed into a brand-new system of urban freight transport based on urban distribution innovations. From the view of physical distribution, urban distribution innovations can be defined as endogenous trends of sustainable urban freight transport. On the basis of the above discussion, this paper employs the literature overview approach to discuss the exogenous and endogenous trends of sustainable urban freight transport.

\subsection{Exogenous Trends: Urban Development}

Urban population growth is a critical element in the generation of urban issues. Figure 6 shows the world's urban population and the average annual rate of change in the period of 1995-2018, and it includes predictions until the year 2030. By 2030, the world's urban population will reach more than 5 billion, and $68 \%$ of the world's population is projected to be living in the city by 2050 [78]. This growth implies that cities need to construct lots of new residential areas and commercial areas. Housing accounts for more than $70 \%$ of land use in most cities and determines urban forms and densities, and one billion new homes are needed worldwide by 2025 [79]. The urban sprawl leads to increases in the numbers of large and megacities around the world. By 2015, there were 44 large cities and 29 megacities [79]. By 2030, the world is projected to have 43 megacities with more than 10 million inhabitants [78] and approximately 67 large cities. From a long-term perspective, the urban range growth has motivated logistics providers to employ two solutions: the usage of infrastructure expansion to increase the delivery range and freight capacity, or the use of more freight fleets to increase the delivery frequency within urban areas. These two solutions exacerbate the conflicts between cities and freights from future perspectives. Infrastructure expansion worsens land-use conflicts and requires logistics providers to increase the cost of construction, operation, and labor. In cities, the locations of new buildings create a traffic demand in the existing network structure [80]. This causes external traffic loadings on the existing network, and it leads to major transportation delays for network users if planning is not optimal [11]. In consequence, this solution restricts the sustainability of urban freight transport in the aspects of economic and social dimensions. As another response solution, although increasing freight fleets can enhance the efficiency of urban logistics, the degree of the increase exacerbates congestion and parking land conflicts within urban areas. Although logistics providers can employ clean-energy mobility approaches (e.g., cargo-bikes and EVs) to reduce emissions, this solution is a barrier to sustainability in the social and environmental dimensions. 


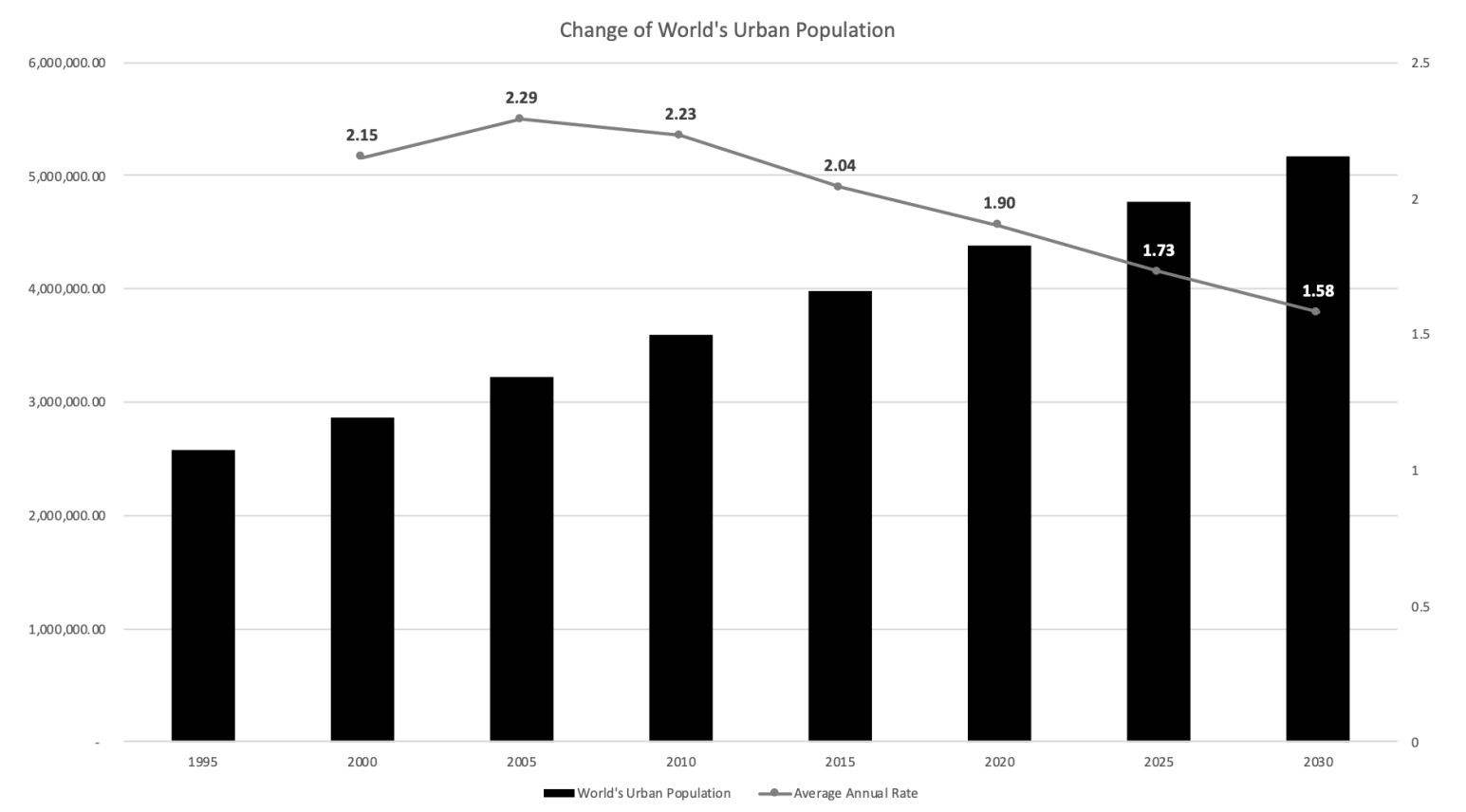

Figure 6. Change in the world's urban population (adapted from [78]).

Additionally, urban demographic expansion and disorganized growth have generated persistent issues and emerging urban challenges [79]. Of these challenges, climate change due to urban emissions has become a core issue for sustainable development. Cities are responsible for more than $70 \%$ of global carbon dioxide emissions [79], and almost $5.5 \%$ of the total annual greenhouse gas emissions are generated by the logistics and transport sectors, around $57 \%$ of which are caused by road freight transport [81]. However, a wide range of research has shown that transportation systems in most cities and urban areas are unsustainable [2]. Although some research on sustainable transport for smart cities has discussed transport emission reduction in future urban planning agendas (e.g., [14,16]), urban freight is still not specifically integrated into the future sustainable urban planning system. Because urban planning is focused principally on passenger transport, sustainable development measures mainly focus on passenger transport [82]. This has resulted in freight transport issues at the city level that are still not well understood or quantified, and there is no methodology aimed explicitly at the analysis and planning of freight movements [82,83]. In recent years, the sustainable urban planning system has integrated transport emission reduction into the future planning agenda. This trend implies that logistics providers need to connect sustainable urban freight strategies to the other modules of the future urban planning agenda, which is at the city level. Although the application of clean-energy freight mobility is an efficient solution for promoting sustainability, sustainable urban freight strategies need to comprehensively consider the whole urban planning schemes at the city level.

As mentioned previously, technological development has motivated the formulation of smart cities. Although this concept is based on the development of information and communications technology (ICT) and the internet of things (IoT), it also influences the physical perspective of urban development, such as zones, infrastructure allocations, and urban transport networks [11,15]. It is noted that universal agreement on a specific definition of a "smart city" is still lacking at present, and its primary field is in the usage of ICT and IoT in the sectors of infrastructure, buildings, and energy [84]. This finding highlights that academia has no consensus about the physical changes in urban development due to the smart city trend. However, it is vital to systematically consider the impacts of the smart city concept on urban development and overall arrangement from physical perspectives.

Besides these factors, changes in the age of the urban population also challenge future sustainable urban logistics. Globally, the fastest-growing population is aged 60 or over at $3.26 \%$ per year; by 
$2050,25 \%$ of the population in all regions except Africa will be aged 60 or over [85]. Compared with this demographic, the youth population (aged 15 to 24) accounts for a further 17\% [86]. The high proportion of these two groups could cause commodity demand polarization. Owing to the physical condition of the aged population, their focus is on health care, medication, daily necessities, and the convenience of pick-up goods, which is provided by urban logistics. In contrast, young people pay more attention to digital products, clothes, delivery security, transport duration, etc. This finding highlights that urban logistics providers need to balance commodity demand polarization to provide differentiated delivery services within future urban areas.

Moreover, suburbanization plays a critical role in the exogenous trends of SUFT. Both economic factors and quality of life have contributed to the movement of urban residents outside congested urban core areas. The reason for this is that land and housing in the suburbs are cheaper than those in city core areas, with low-density living, often resulting in a better quality of life and improved access to amenities [79]. It is noted that the ensuing pattern of urban development consists of the displacement of population, movement of industries and services from the city center to the periphery, and the creation of new centers with their own economic and social dynamics [79]. This finding implies that the distribution change in urban areas aggravates the negative environmental externalities caused by delivery frequency growth and freight range extension.

In sum, exogenous trends have radically influenced the conventional urban freight system. Although the usage of clean-energy mobility contributes to a decrease in emissions and thereby promotes the sustainability of urban freight transport, both urban development trends and urban population growth can restrict the other components of sustainability dimensions (i.e., Social and Economic). For example, traffic congestion caused by delivery frequency rises, and infrastructure expansion exacerbates land-use conflicts. Therefore, the long-term planning of sustainable urban freight transport needs to systematically consider these exogenous trends. The objective is to design a flexible and sustainable urban freight system to respond to the future challenges of urban development. To answer RQ 3, this paper further discusses appropriate methods, which can be used to analyze these exogenous trends and connect them to research on the long-term planning of SUFT.

\subsection{Endogenous Trends: Urban Distribution Innovations}

As mentioned previously, the notion of smart cities has motivated the application of innovative transport mobility in the urban transport system. An example is autonomous vehicles [14]. The use of urban distribution innovations is an efficient solution for promoting sustainable urban freight transport. The definition of urban distribution innovations is the application of emerging transport modes to reduce the negative impacts of urban freight movements, thereby promoting the sustainability of city logistics [17]. According to the literature review, there are eleven urban distribution innovations: electric vehicles (EVs), public transit logistics, taxi logistics, cargo-bikes, parcel lockers, delivery drones, robotic vehicles, delivery robots, modular vehicles, mobile depots, and urban freight ships.

Table 4 defines these eleven distribution innovations and the applicative implementation process in urban freight transport. By retrieving and filtering the literature, we determined that considerable research has paid scant attention to the integration of urban distribution innovations that operate together as a system. At present, there is very little research work and few systematically prepared findings in this area. The integration of urban distribution innovations is an efficient solution for further promoting sustainable urban freight transport [17]. Lots of logistics providers and technology companies have indeed launched similar concepts for future SUFT. For example, DHL Express (2017) piloted the City Hub concept in Frankfurt, Germany, and Utrecht, Netherlands; the vehicles are combined with a customized trailer carrying up to four small containers, and they then use DHL Cubicycles (a cargo-bike that is able to carry a container) to complete last-mile delivery [87]; Workhorse Group developed the HorseFly UAV Delivery system, which is fully integrated with electric/hybrid delivery trucks, while UPS has tested residential delivery with drones launched from atop a package 
car [88]. These projects demonstrated that the operational integration of different urban distribution innovations is an irreversible trend for future sustainable urban freight transport.

Additionally, some research has examined operational integration based on partial distribution innovations. For example, Kikuta et al. (2012) [89] mentioned that Yamato Transport Co. (Tokyo, Japan) has been adopting a tram system for transshipping goods to Arashiyama in Kyoto and then using cargo-bikes to conduct last-mile delivery within urban areas. He and Haasis (2019) [17] proposed the concept of sustainable inner-urban intermodal transportation, which integrates these eleven distribution innovations with small standardized containers. Nevertheless, much less research has focused on systematically selecting these different innovations to construct delivery strategies for future sustainable urban freight transport. It is noted that a systematic selection method prompts logistics providers to construct efficient, sustainable freight strategies for future cities. This finding also highlights that systematic consideration of the operational integration of distribution innovations is necessary for future SUFT.

Table 4. Distribution of the eleven topics in distribution innovations (adapted from [17]).

\begin{tabular}{|c|c|c|c|}
\hline Topic & Describing & $\begin{array}{l}\text { Transshipment } \\
\text { Transportation }\end{array}$ & $\begin{array}{l}\text { Last-Mile } \\
\text { Delivery }\end{array}$ \\
\hline Electric vehicles & $\begin{array}{l}\text { Applied E-vehicles to transport goods in } \\
\text { urban areas }\end{array}$ & $\times$ & $\times$ \\
\hline Modular E-vehicles & $\begin{array}{l}\text { A special type of vehicle is used to deliver } \\
\text { the goods to consumers by carrying one or } \\
\text { multiple cabin modules }\end{array}$ & & $\times$ \\
\hline Public transit logistics & $\begin{array}{l}\text { Integrated passenger and freight activities } \\
\text { (i.e., tram, subway, bus) }\end{array}$ & $x$ & $x$ \\
\hline Urban freight ships & $\begin{array}{l}\text { Utilized a ship to transfer goods to transit } \\
\text { points by the inland waterway of the city }\end{array}$ & $x$ & $x$ \\
\hline Taxi logistics & $\begin{array}{l}\text { Applied taxis to transport goods; the } \\
\text { purpose is to reduce traffic congestion }\end{array}$ & $\times$ & \\
\hline Cargo-bike & $\begin{array}{l}\text { Use of a cargo-bike for freight distribution } \\
\text { in city centers }\end{array}$ & & $x$ \\
\hline Robotic vehicles & $\begin{array}{l}\text { Use of autonomous (robotic) vehicles for } \\
\text { freight distribution in city areas }\end{array}$ & & $x$ \\
\hline Delivery drones & $\begin{array}{l}\text { Use of drones for freight delivery in city } \\
\text { areas }\end{array}$ & & $\times$ \\
\hline Delivery robots & $\begin{array}{l}\text { Use of small robots to deliver goods to the } \\
\text { destination }\end{array}$ & & $x$ \\
\hline Parcel lockers & $\begin{array}{l}\text { The implementation of parcel lockers aims to } \\
\text { reduce traffic congestion in residential areas } \\
\text { and enhance the efficiency of delivery }\end{array}$ & & $x$ \\
\hline Mobile depot & $\begin{array}{l}\text { A mobile depot is a trailer fitted with a } \\
\text { loading dock, warehousing facilities, and an } \\
\text { office }\end{array}$ & & $x$ \\
\hline
\end{tabular}

In sum, both exogenous and endogenous trends have radically influenced the short-term planning of sustainable urban freight transport. The result in Section 3 indicates that, thus far, there is very little research and few systematically prepared findings for the long-term planning of SUFT. The previous analysis demonstrates that the long-term planning of SUFT needs to systematically discuss and integrate the consideration of these two trends. Therefore, the selection of the appropriate research 
methods plays a critical role in developing a theoretical framework of future sustainable urban freight transport. Furthermore, exogenous and endogenous trends maintain a set of relations that influence each other. The operational integration of distribution innovations needs to consider the future trends of urban development. Meanwhile, sustainable strategies of urban planning have to integrate urban freight transport into the urban development agenda. Because exogenous and endogenous trends have interlocking and complex components in urban freight planning, selecting appropriate research methods is a critical step for constructing a framework. In view of this, this paper discusses foresight research methods that are suitable for investigating both exogenous and endogenous trends.

\section{Appropriate Methodology Selection}

Despite the fact that the nine approaches were employed in the article corpus, these methods are not enough to construct a feasible framework for future sustainable urban freight transport. Concurrently, the feasibility of a distinct methods mix must also be further discussed after determining the appropriate methods. Therefore, this section analyzes the impacts of urban development and distribution innovations on future urban freight transport. Furthermore, this paper follows the general framework of foresight research to systematically discuss method selection and the feasibility of methods mix.

\subsection{Fundamental Elements of Foresight Research Framework}

In academic discourse, the term Foresight is used to delineate forecasting and emphasize the explorative nature of the processes involved [90], while it is also the capacity to systematically think toward the future to inform decision-making today [91]. Furthermore, a considerable number of scholars suggest that foresight research is future-oriented, which needs a long-term (the next 10 to 25 years or more) view (i.e., [92-94]). Therefore, the approach of foresight (future) research is "the tools, methods and thinking styles used to build an organizational foresight capacity, usually interdisciplinary and inclusive rather than restricted to a particular philosophy, discipline or method" [91]. Additionally, the approaches use a longer-term (10 to 20 or more years) timeframe to facilitate thinking that moves beyond the boundaries of convention and the status quo [91].

Following the understanding of the relevant concept of foresight research, its general framework needs to be discussed further. Popper (2008) [76] demonstrated the general framework of foresight research, as depicted in Figure 7 . His research demonstrated that foresight research is a systematic process with five interconnected and complementary phases: (1) Pre-foresight phase, (2) Recruitment phase, (3) Generation phase, (4) Action phase, and (5) Renewal phase. In the general framework of the foresight process, the "methods mix" refers to the combination of foresight methods, with 25 approaches used in 886 cases [76]. In the article by Popper, these sets of data are cited from the European Foresight Monitoring Network (EFMN) (EFMN, https:/ / www.efmn.eu) and Strategic Euro-Latin Foresight Research and University Learning Exchange (SELF-RULE) (SELF-RULE, www.self-rule.org). Figure 8 depicts these 25 approaches, as well as their frequency of use in the 886 cases. The usage of the literature review (LR) accounts for almost $54 \%$, which makes it the most extensively used method in these cases. Besides the LR, foresight methods also include the future workshop, key technologies, interviews, technology road mapping, cross-impact/structural analysis, and morphological analysis. Because there are 25 foresight research methods, selecting the appropriate method is a critical success element for the long-term planning of sustainable urban freight transport. 


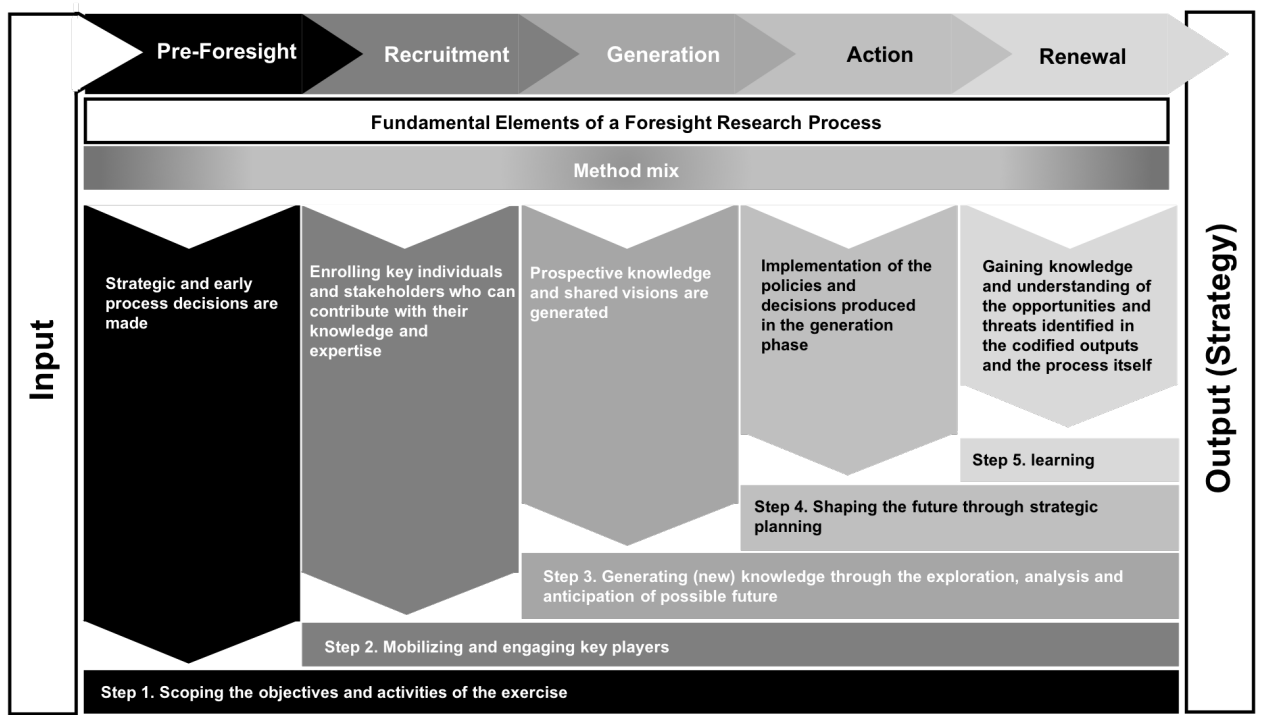

Figure 7. General framework of foresight research (Adapted from [76]).

Selecting the appropriate foresight research methods plays a critical role in the response to RQ 4. Of these 25 methods, the qualitative methods are more widely used than quantitative and semi-quantitative ones [76], such as the LR, expert panels, trend extrapolation/megatrends, and morphological analysis. This result is probably attributable to the fact that "the study of the future is inevitably informed by opinions and judgments based on subjective and creative interpretations of the changes (or lack of changes) creating or shaping the future" [76]. To answer RQ 3, this paper discusses and selects the appropriate foresight research methods and follows the general framework of foresight research.

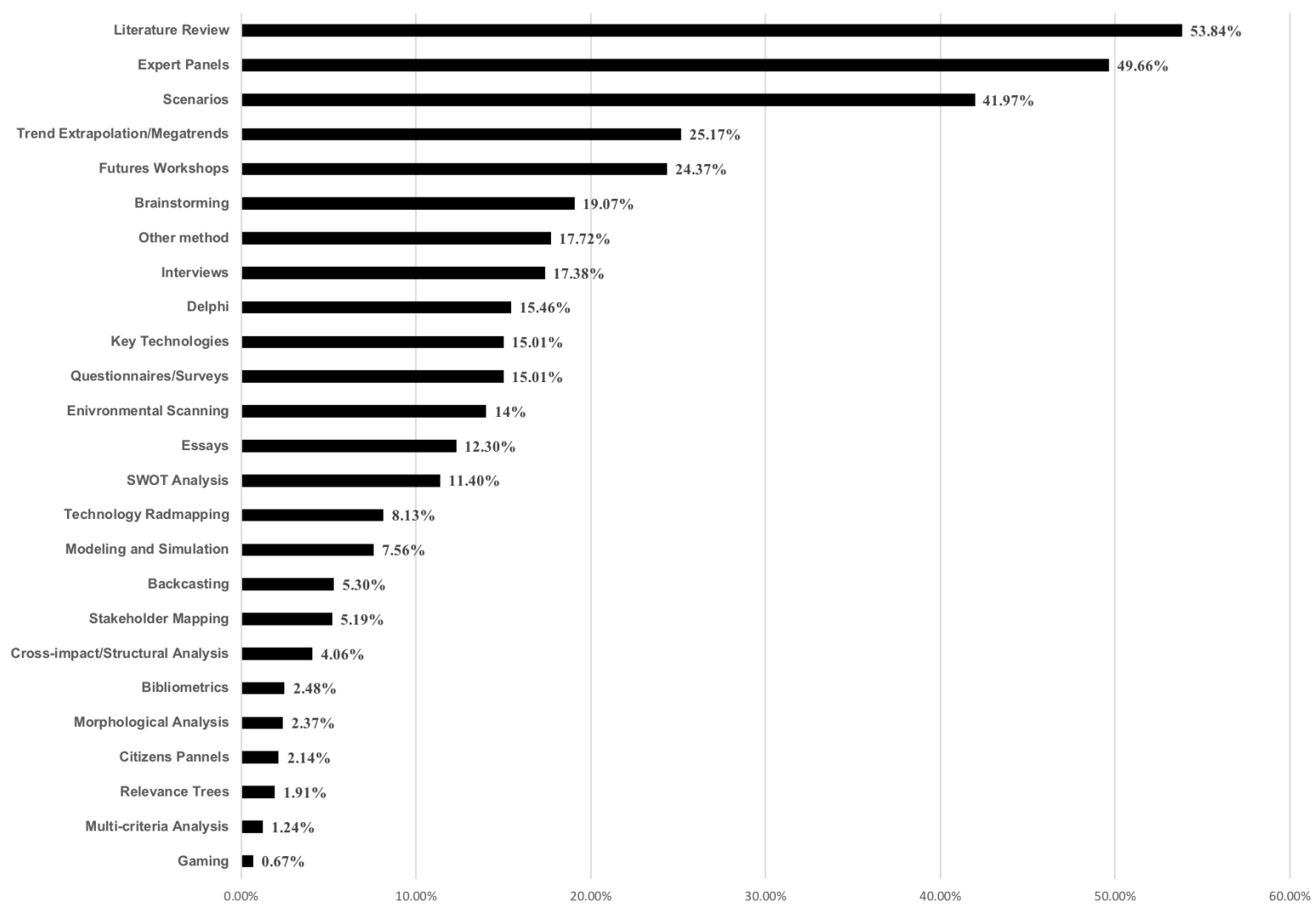

Figure 8. Frequency of use for 25 foresight research methods (Adapted from [76], which is based on EMFN and SELF-RULE). 


\subsection{Method Selection of Foresight Research on Future Sustainable Urban Logistics}

From the previous discussion, there are 25 methods that can be used in foresight research. To answer RQ 3, this paper selects and discusses the appropriate research approaches, as well as the issues of city logistics. The details are presented below.

\section{(1) The method of trend extrapolation/megatrends}

This method has been described as being "Among the longest-established tools of forecasting; They provide a rough idea of how past and present developments may look like in the future-assuming, to some extent, that the future is a continuation of the past" [76]. City logistics is a complex system that involves stakeholders, environmental externalities, benefit-cost balance, and other issues. The sustainable urban freight system is a popular topic in this field because it will play a crucial role in sustainable and livable cities in the future. Nevertheless, considerable research has paid scant attention to the links between urban freight planning and the trends of city development [8]. Concurrently, city development is an exogenous trend that has radically influenced the urban freight system. For example, urbanization has increased the delivery range of city logistics; the urban population growth has exacerbated both the congestion and emissions created by increased freight demands.

To respond to these trends, urban logistics providers aim to find appropriate endogenous solutions to promote the sustainability of urban freight. In fact, many issues of city logistics surround transport modes. An example is the environmental externalities created by freight activities, which include emissions, congestion, and noise [3,4]. In consequence, the majority of technology enterprises have launched/produced projects on emerging transport modes for urban freight transport. An example is the Velove Armadillo cargo-bike produced by the Swedish company Velove [95]. Moreover, the logistics provider has developed emerging operational strategies based on urban distribution innovations. For instance, DHL Express piloted the City Hub concept (2017) in which vehicles are combined with a customized trailer carrying up to four containers and then use DHL Cubicycles (a cargo-bike able to carry a container) to complete last-mile delivery [87]. Therefore, the use of distribution innovations, such as the implementation of electric vehicles to reduce the emissions created by freight activities, is an efficient solution for the future urban freight system [17].

To this end, understanding the future trends of both urban development and city logistics plays a critical role in foresight research on sustainable urban freight planning. Furthermore, it is critical to analyze both the interactions between them and their impacts on each other. The next problem is understanding the future trends of cities and freights. On the basis of the frequency of the foresight method used, we selected the LR method to discuss the specific content of both trends.

\section{(2) The literature review method.}

The LR method is an environmental scanning process that is constructed around the themes and related theories of relevant articles [76]. The systematic literature review (SLR), as a specific method, is extensively used. As mentioned previously, foresight research on sustainable urban freight planning needs to understand the exogenous and endogenous trends of urban freight transport, namely, the trends of urban development and the trends of urban distribution innovations. The LR method is a suitable approach to understanding both trends in response to these problems. It is noted that, from the view of future urban freight planning, the application of emerging transport mobility has changed the conventional urban freight network [17]. For example, the urban freight tram/metro system uses the integrated transit station, which changes the freight network structure into a multi-tier (three/four tiers) structure (e.g., [96-98]). It is foreseeable that various distribution innovations will operate together as a system in the future. The collaboration and integration of distinct distribution innovations have increasingly become future trends of sustainable urban logistics. From the view of long-term planning, this finding implies that the application of various distribution innovations in the future could possibly exacerbate the inflexibility of the conventional urban freight network. To this end, the first question of $\mathrm{LR}$ is the research status regarding urban freight network design and urban distribution innovations, 
which need to be analyzed and discussed further. Meanwhile, the interaction and impacts of both topics also have to be further analyzed and discussed from a futurology perspective.

In recent decades, urban development has exacerbated the challenges of city logistics. Urban population growth is the primary element that has caused persistent issues and emerging urban challenges [79]. Finally, the impacts of these issues and challenges on the urban freight system require an in-depth discussion and further analysis. The usage of the literature review contributes to an understanding of the specific content of future trends in urban development. Therefore, we determined that the LR method is an efficient and appropriate approach for understanding the future trends of both city development and urban distribution innovations. Additionally, the dimensions of designing future sustainable urban freight systems include the urban freight network structure and emerging operation strategies. The objective of the future sustainable urban freight system design further promotes sustainability from the perspectives of environmental, social, and economic dimensions. It aims to increase the flexibility of the conventional urban freight network structure. The next step is to select an appropriate foresight method to design the future urban freight system.

\section{(3) The morphological analysis method.}

The morphological analysis method entails systematically structuring and comprehensively studying the total set of relationships contained in multi-dimensional, non-quantifiable problem complexes $[99,100]$. This method enables us to systematically predict possible future technologies and feasible solutions. As mentioned previously, foresight research on city logistics needs to comprehensively consider three dimensions: the trends of city development, the application of urban distribution innovations, as well as the network structure of the urban freight system. Meanwhile, the interactions between each dimension and their impacts on each other need to be further studied from a multi-dimensional view.

Moreover, future trends of applied urban distribution innovations use an integrated approach to compose emerging operational strategies [17], such as the concept of "sustainable inner-urban intermodal transportation" [17] and the "city logistics hubs" launched by DHL (Germany). Given that multiple distribution innovations will presumably be used in the future urban freight system, the selection of these innovations and their combination is also an investigated topic in the foresight research on urban logistics. It is noted that this topic is also a multi-dimensional and non-quantifiable issue. Besides the operational integration of urban distribution innovations, considerable technology enterprises have launched several specific projects to develop emerging transport mobility. An example is the ZF Friedrichshafen AG (Germany) proposal of the Autonomous Depot, which is a robotic vehicle equipped with parcel lockers (as depicted in Figure 9). From the view of technology companies, integrated technologies of various distribution innovations are able to develop brand-new transport modes for future city logistics. Forecasting the possible future transport modes is also a crucial component for the long-term planning of sustainable urban freight transport. Because the application of different transport modes has influenced the freight network structure, the prediction of future technologies contributes to the design of a flexible network structure from a long-term view, which thereby further promotes sustainability. These findings, as discussed previously, highlight that the morphological analysis method is an efficient solution for foresight research on future urban logistics. 


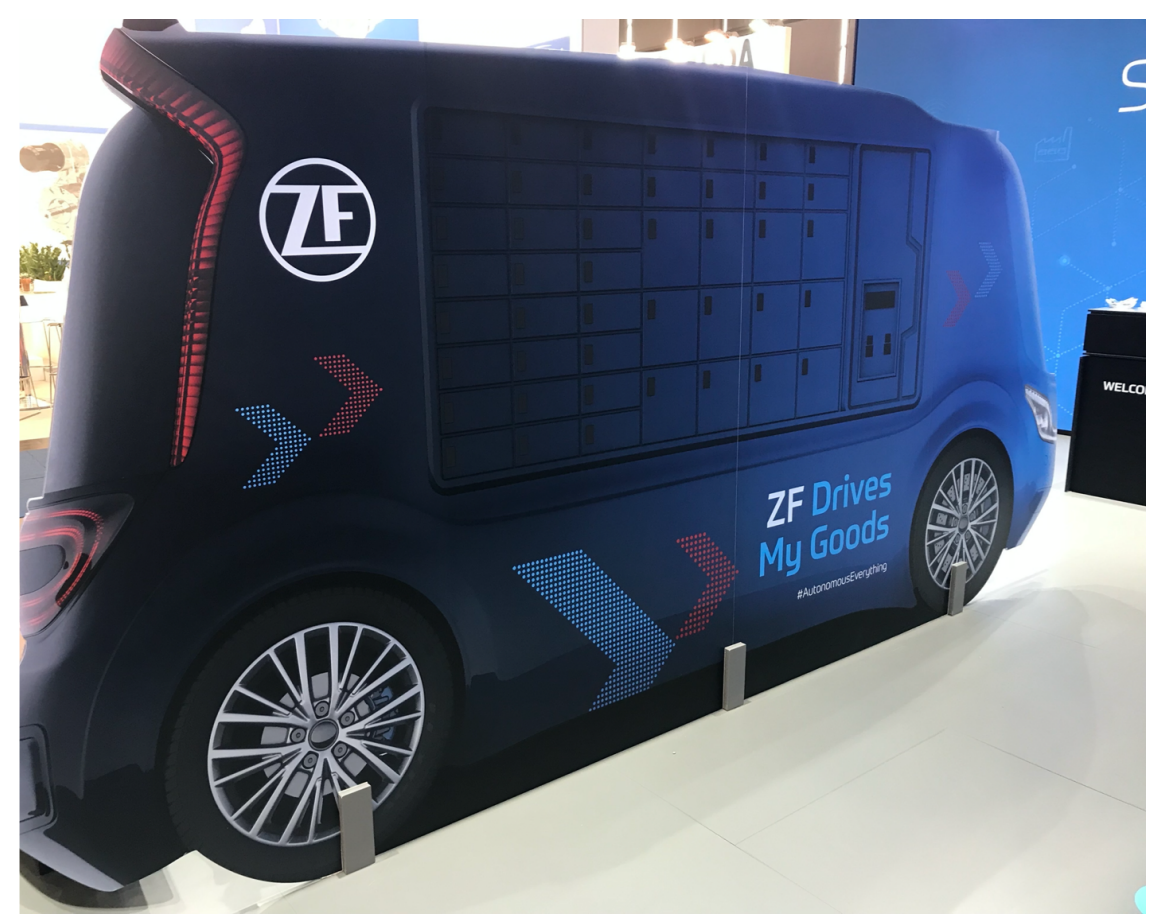

Figure 9. Autonomous depot proposed by ZF Friedrichshafen AG (Photo by Authors, Hannover Messe 2019, Germany).

After determining possible future distribution models in city logistics, the next step is to design a flexible and sustainable urban freight network structure. Indeed, considerable research on city logistics planning has been mainly based on the conventional urban freight network structure, namely, a single-tier or two-tier system. The research perspective of these articles is also from the view of short-term planning. As mentioned previously, foresight research focuses on long-term planning. The morphological analysis method contributes to an understanding of future urban logistics. Morphological analysis contributes to the design of a flexible urban freight network structure because it is a qualitative methodology for the systematic consideration of all external factors. This finding reveals that the usage of morphological analysis is a suitable method to design the future urban freight system, particularly after understanding the megatrends of cities and freights.

\subsection{The Feasibility of Methods Mix}

On the basis of the previous discussion, this paper identifies appropriate methods for foresight research on the future sustainable urban freight system. These methods consist of trend extrapolation/megatrends, literature review, and morphological analysis. Following the general framework of foresight research (Figure 7), the next step is to further analyze the feasibility of the methods mix. This process aims to understand the relationships among methods and their influences on each other by creating a methods combination matrix (MCM). The process of constructing an MCM was previously described by Popper: "this matrix involved crossing the variable methods against itself (originally producing a symmetric matrix) and dividing each row by the respective value in the diagonal, which indicates the total number of times a method was used in a sample of 886 cases" [76]. Given this, this paper further discusses the feasibility of the method mix that consists of trend extrapolation/megatrends, literature review, and morphological analysis.

Table 5 demonstrates that the method combination of LR and trend extrapolation/megatrends is a "high combination" that accounts for almost 40-59\% of the 886 cases. Furthermore, the method combination of LR and morphological analysis is a "very high combination" that accounts for more than approximately $60 \%$. Finally, the method combination of trend extrapolation/megatrends and morphological analysis is also a "high combination". This finding reveals that combinations of these 
three methods have been widely used in foresight research. In the previous section, the suitabilities of these three methods were separately discussed for foresight research on city logistics. Combined with the feasibility of the methods mix, these three identified methods were ultimately used to develop the theoretical framework of foresight research on sustainable urban freight transport.

Table 5. Frequency of using the methods mix (Adapted from [76], which is based on EMFN and SELF-RULE).

\begin{tabular}{cccc}
\hline & $\begin{array}{c}\text { Trend } \\
\text { Extrapolation/Megatrends }\end{array}$ & $\begin{array}{c}\text { Literature } \\
\text { Review }\end{array}$ & $\begin{array}{c}\text { Morphological } \\
\text { Analysis }\end{array}$ \\
\hline Trend Extrapolation/Megatrends & - & Very high & High \\
\hline Literature Review & Very high & - & Very high \\
\hline Morphological Analysis & High & Very high & - \\
\hline
\end{tabular}

\section{Theoretical Research Framework of Future SUFT}

To answer RQ 4, we define the research method as the vertical dimension of the framework and the research elements as its horizontal dimension. The three selected methods of foresight research are trend extrapolation/megatrends, literature review, and morphological analysis. Following the general framework of foresight research, the research elements include three dimensions: urban development, distribution innovations, and the urban network structure. Moreover, the urban freight network is primarily composed of transport fleets, infrastructures, and destination locations from the view of physical transport. It is noted that, besides the vertical and horizontal dimensions of the framework, sustainable transition also has a critical role in city logistics. On the basis of these discussions, the components of the framework are identified.

Although logistics providers and technology enterprises have promoted innovative transport modes to achieve sustainability, currently, these emerging strategies are unable to entirely replace the original system. This is because relevant companies need to comprehensively consider the cost of emerging transport strategies, as well as the urban land-use conflict of constructing new infrastructure. Therefore, logistics providers have commonly used a transition perspective to develop appropriate operation measures. According to the literature review, the transition perspective can be understood as being based on the co-evolution of different actors on different levels [101], and a significant component of innovation is the new combination of existing elements [102]. In fact, both logistics providers and technology enterprises have promoted a sustainable transition process as being involved in the combination of existing and emerging elements. This combination includes infrastructure, transport modes, as well as strategy/policy. The sustainable transition process is a nonlinear, complex, and long-term process that results from the interplay of development [18]. In consequence, from the view of long-term planning, logistics providers have commonly used new technologies/infrastructures/strategies to connect to old technologies in the form of an auxiliary add-on, thereby improving its functioning [18]. This process is likewise used for new infrastructure that supports the application of emerging transport modes. Moreover, sustainable transition can promote the sustainability of the urban freight system from the perspectives of saving costs and decreasing environmental externalities, among other benefits.

Figure 10 shows the theoretical research framework of future sustainable urban freight transport. This framework provides a research model with which urban logistics providers can make the transition to a flexible and sustainable system of urban freight. It also helps logistics providers to better accommodate the exogenous and endogenous trends of urban freight transport from a long-term view. 
First, the methods mix that consists of trend extrapolation/megatrends and literature review is used to discuss the exogenous and endogenous trends of sustainable urban logistics. After that, the impacts of urban distribution innovations on the conventional urban freight network need to be further analyzed while detecting the research gaps between these two topics on the basis of the systematic literature review. Following the previous discussions, the next step is to use the morphological analysis method to study the future strategy of urban freight distribution. Subsequently, analyzing the implication of exogenous trends for the conventional urban freight network is necessary. Finally, the previous two steps are integrated to discuss the future urban freight network structure, thereby further promoting its sustainability and flexibility.

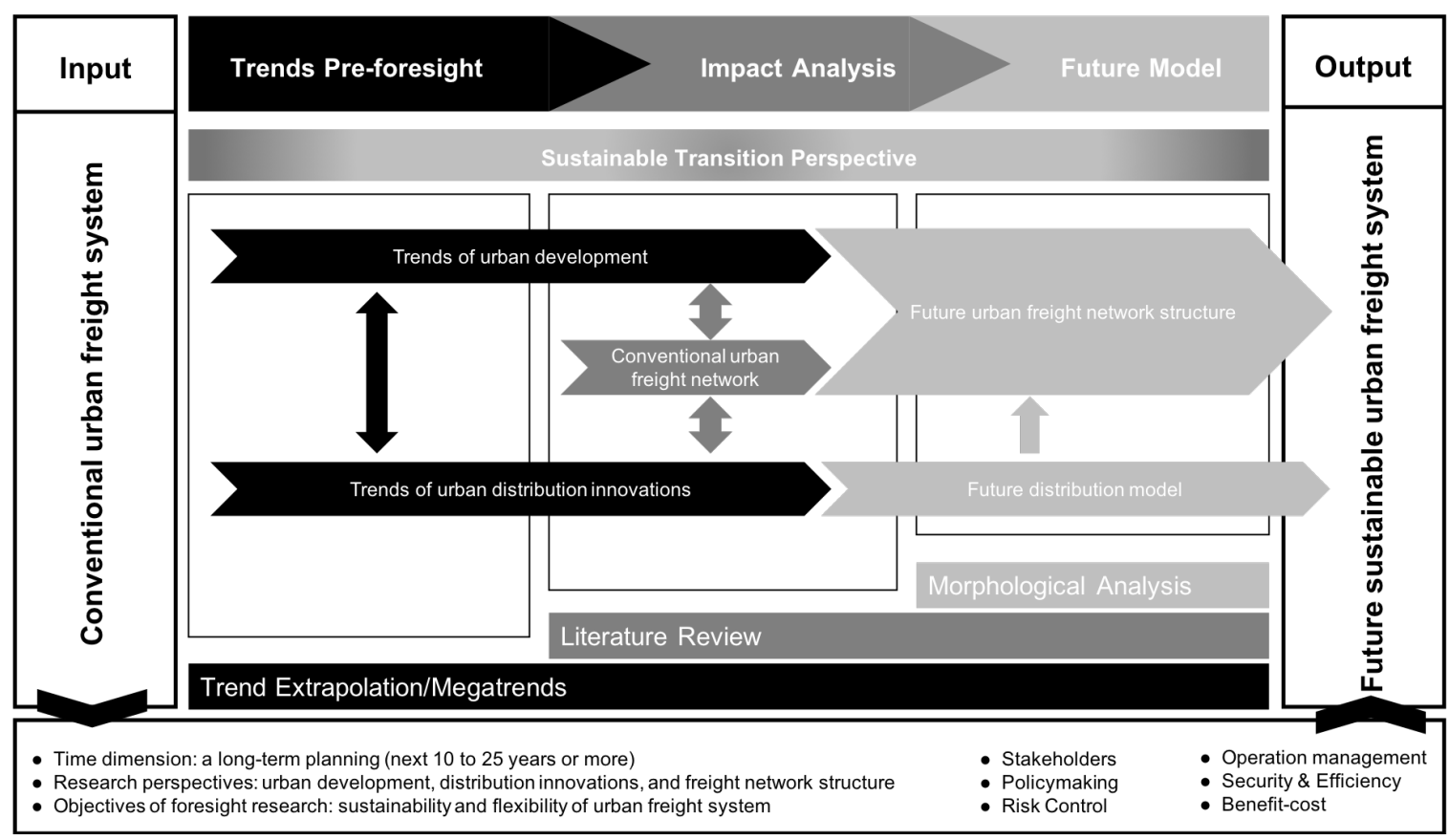

Figure 10. Theoretical research framework of future sustainable urban freight transport (Source: Authors' own elaboration).

Figure 11 demonstrates more details related to this research framework. First, the methods mix that consists of literature review and trend extrapolation is used to understand the exogenous and endogenous trends of future sustainable urban freight transport. Furthermore, cross-impact analysis is intended to determine the impact factors of both trends on sustainable urban freight transport; these impacts are the parameters in the morphological matrix. After that, the morphological analysis approach is employed to construct the appropriate strategies for sustainable urban freight transport with a long-term perspective. Finally, the network structure of the future sustainable urban freight transport needs further discussion based on innovative sustainable urban freight strategies. The evaluation and assessment system consists of sustainability, flexibility, and external criteria. Sustainability includes three dimensions: environment, economy, and society. The flexibility evaluation is based on three aspects: the passive expansion of logistics infrastructure, the passive increase of freight fleets, and the determination of whether to address short-term issues or not. Besides these, there are three external criteria: benefit-cost analysis, efficiency assessment, and security evaluation. From a long-term view, endogenous trends potentially change the stakeholders. An example is the usage of public transit logistics, which integrates the passenger and freight within urban areas. Additionally, the research on future sustainable urban freight transport needs to consider decision support and the formulation of urban freight policy. Moreover, the application of distribution innovations has to be supported by information and communications technology (e.g., the control platform for delivery robots and drones). Although the current urban planning agenda focuses 
on the passenger, integrating sustainable freight into the urban planning agenda contributes to the formulation of long-term sustainable strategies for cities. Furthermore, consumers' behaviors change, and technological innovations (e.g., 3D printer) are critical components of the long-term planning of SUFT. Meanwhile, replacement strategies of freight vehicles need to be further discussed from a transition perspective.

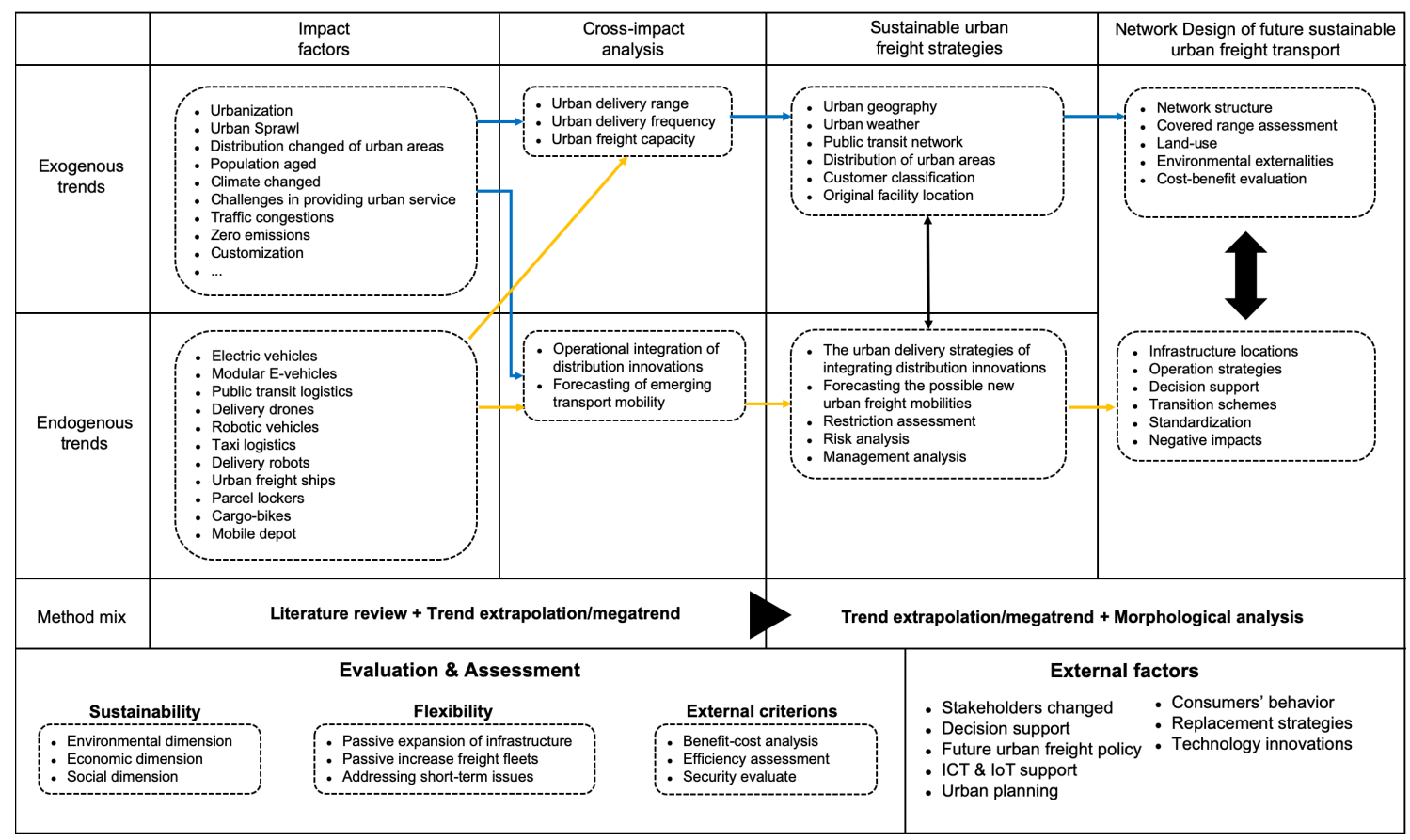

Figure 11. Description of the theoretical research framework of future sustainable urban freight transport (Source: Authors' own elaboration).

This framework aims to handle the challenges of city logistics created by the exogenous and endogenous trends of urban freight. In addition to these issues, some external factors also need to be considered systematically. Indeed, research on the urban freight system needs to systematically consider many elements because city logistics is a complex system that involves multiple dimensions (e.g., stakeholders, infrastructures, and policy-making). Foresight research on sustainable city logistics also needs to consider these dimensions. The interplay among stakeholders is a critical factor in the policy-making of city logistics. This sustainable transition process can possibly change the relations among stakeholders. It is noted that the application of emerging transport modes also needs the support of urban freight policy for certain aspects, such as constructing tram transit stations that integrate the passenger and freight and using delivery drones within urban areas. Hence, both urban freight policy-making and stakeholders' impacts are critical components of research on the future urban freight system in long-term planning.

Additionally, logistics providers are primarily concerned with risk evaluation and operation management under this sustainable transition. The possible risks include laws, costs, as well as the security and effectiveness of urban delivery. Because each city contains gaps in real situations, risk evaluation contributes to the logistics providers' ability to better achieve the goals of transition, namely, sustainability and flexibility. From the view of operations management, the integration of various distribution innovations that operate together as a system is an emerging challenge for logistics providers. Likewise, these challenges exacerbate the possible risks, which also need to be predicted and controlled through foresight research. In conclusion, future research directions need to comprehensively consider these elements through foresight research on the urban freight system. 


\section{The Sustainability of Future SUFT}

The definition of sustainable development is "a development that meets the needs of the present without compromising the ability of future generations to meet their own needs" [103]. The principles of sustainable urban transport include three dimensions: social equity, economic growth, and environmental protection. As demonstrated by Behrends et al. (2008) [82], a SUFT system needs to fulfill all the following objectives:

- to ensure the accessibility offered by the transport system to all categories of freight transport;

- to reduce air pollution, greenhouse gas emissions, waste, and noise to levels that do not have negative impacts on the health of citizens or nature;

- to improve the resource- and energy-efficiency and cost-effectiveness of the transportation of goods, taking into account external costs; and

- to contribute to the enhancement of the attractiveness and quality of the urban environment by avoiding accidents and minimizing the use of land without compromising the mobility of citizens.

According to the previous discussion, it is vital to systematically consider exogenous and endogenous trends to design future sustainable urban freight transport. Admittedly, applying distribution innovations is performed to a degree that reduces negative environmental externalities, which can promote sustainability from the dimension of environmental protection. Nevertheless, the fragmented application of distribution innovations increases the total costs for logistics providers, exacerbates urban space conflicts, and challenges the capacity of existing transport networks. From the economic and social dimensions, it restricts the further promotion of sustainability. The sustainability of future SUFT needs to balance these three dimensions simultaneously. It aims to find an optimal solution, which is not the best solution for one dimension.

Although most cities have formulated a sustainable development agenda, thus far, the transportation systems in most cities and urban areas are unsustainable. The main reason is that it is hard to generate a systematic agenda of sustainable urban planning with a long-term view under ineffective and fragmented urban governance [79]. Meanwhile, the urban planning system is focused principally on passenger transport [82]. This has caused urban freight to remain marginalized in sustainable urban planning. This finding reveals that the future SUFT needs to comprehensively consider urban development to formulate sustainable strategies that connect with sustainable urban development strategies at the city level. Additionally, the notion of smart cities has changed the original sustainable urban planning agenda. Although a universal agreement on the definition is lacking, academia has agreed that it radically influences building allocation and urban transport. The development of ICT and IoT is also an emerging challenge for the information security of urban freight customers and logistics providers. Therefore, future SUFT also needs to reduce the risks of information security as much as possible, thereby promoting sustainability in the social dimension.

\section{Conclusions}

This paper presents a theoretical research framework of future sustainable urban freight transport while discussing appropriate methods. At present, to the best of our knowledge, long-term planning of SUFT is lacking. Accompanied by the urban development and application of distribution innovations, this gap could possibly restrict the further sustainability of UFT in future cities. City development has exacerbated the challenges of city logistics, particularly in large/megacities around the world. The trends of city development, as exogenous trends of urban freight, have motivated logistics providers to find endogenous solutions to cope with these challenges. From a short-term view, usage of urban distribution innovations is an efficient solution to promote the sustainable urban freight system. Nevertheless, considerable research has paid scant attention to the impacts of both urban development and distribution innovations in the conventional urban freight system. As a response 
to this gap, the application of foresight methods is an efficient solution for researching the long-term planning of SUFT in these two aspects.

Given this situation, we employed the SLR to find literature on foresight research published within the past sixteen years (2003-2018). Subsequently, we systematically analyzed the impacts of exogenous and endogenous trends on future SUFT. This step enabled the selection of appropriate research methods to construct the theoretical framework. In order to ensure the feasibility of the theoretical framework, we integrated it with the theory of transition perspective. A combination of existing and emerging elements is a critical component of the current urban freight system, which will transition to the future system. This combination has involved infrastructures, transport modes, policies, etc. Because urban freight transport is a complex system, multiple dimensions need to be comprehensively considered in research on city logistics. On the basis of the theoretical framework, the dimensions of stakeholders, policy, risk evaluation, and management have also been discussed.

The limitations of this paper include the followed aspects. First, urban development is also influenced by the decisions of the local government. The authorities adjust to the model of urban development on the basis of the investment environment, economic positioning, and geopolitics. This framework does not further expand on this point. Additionally, this framework does not further address the impacts of external technologies on sustainable urban logistics, such as the 3D printer. Hence, future studies will include these limitations to strengthen and test the framework. We believe that this paper can assist practitioners and researchers to better orient their efforts toward promoting sustainable city logistics in the future.

Author Contributions: In this paper, Z.H. developed the research ideas, analyzed the results, as well as completed the original writing of the paper. The research methodology was designed by H.-D.H. and Z.H. together. Furthermore, H.-D.H. reviewed the paper. All authors have read and agreed to the published version of the manuscript.

Funding: This research received no external funding.

Acknowledgments: The publication of this paper was supported by Staats- und Universitaetsbibliothek Bremen (SuUB), Germany.

Conflicts of Interest: The authors declare no conflict of interest.

\section{References}

1. Rassafi, A.; Vaziri, M. Sustainable transport indicators: Definition and integration. Int. J. Environ. Sci. Technol. 2005, 2, 83-96. [CrossRef]

2. Bamwesigye, D.; Hlavackova, P. Analysis of Sustainable Transport for Smart Cities. Sustainability 2019, 11, 2140. [CrossRef]

3. Anderson, S.; Allen, J.; Browne, M. Urban logistics-how can it meet policy makers' sustainability objectives? J. Transp. Geogr. 2005, 13, 71-81. [CrossRef]

4. Wittlöv, A. Urban freight transport: Challenges and opportunities. In Urban Freight for Livable Cities: How to Deal with Collaboration and Trade-Offs; Tryckeri AB Orion: Täby, Sweden, 2012; pp. 12-23.

5. Initiative, G.R. G4 Sustainability Reporting Guidelines: Reporting Principles and Standard Disclosures; Global Reporting Initiative: Amsterdam, The Netherlands, 2013; pp. 7-14.

6. Dablanc, L. Goods transport in large European cities: Difficult to organize, difficult to modernize. Transp. Res. Part A Policy Pract. 2007, 41, 280-285. [CrossRef]

7. Benjelloun, A.; Crainic, T.G. Trends, challenges, and perspectives in city logistics. Bul. AGIR 2009, 4, $269-284$.

8. Cui, J.; Dodson, J.; Hall, P.V. Planning for urban freight transport: An overview. Transp. Rev. 2015, 35, 583-598. [CrossRef]

9. Wolfram, M.; Consult, R. Expert Working Group on Sustainable Urban Transport Plans; Rupprecht Consult: Cologne, Germany, 2004.

10. Ehmke, J. Integration of Information and Optimization Models for Routing in City Logistics; Springer Science and Business Media: Berlin/Heidelberg, Germany, 2012.

11. Hammad, A.W.; Akbarnezhad, A.; Haddad, A.; Vazquez, E.G. Sustainable Zoning, Land-Use Allocation and Facility Location Optimisation in Smart Cities. Energies 2019, 12, 1318. [CrossRef] 
12. Ferraris, A.; Santoro, G.; Papa, A. The cities of the future: Hybrid alliances for open innovation projects. Futures 2018, 103, 51-60. [CrossRef]

13. Al-Thani, S.K.; Skelhorn, C.P.; Amato, A.; Koc, M.; Al-Ghamdi, S.G. Smart technology impact on neighborhood form for a sustainable Doha. Sustainability 2018, 10, 4764. [CrossRef]

14. Freudendal-Pedersen, M.; Kesselring, S.; Servou, E. What is smart for the future city? Mobilities and automation. Sustainability 2019, 11, 221. [CrossRef]

15. Tobey, M.B.; Binder, R.B.; Chang, S.; Yoshida, T.; Yamagata, Y.; Yang, P.P. Urban Systems Design: A Conceptual Framework for Planning Smart Communities. Smart Cities 2019, 2, 522-537. [CrossRef]

16. Behrendt, F. Cycling the smart and sustainable city: Analyzing EC policy documents on internet of things, mobility and transport, and smart cities. Sustainability 2019, 11, 763. [CrossRef]

17. He, Z.; Haasis, H.D. Integration of Urban Freight Innovations: Sustainable Inner-Urban Intermodal Transportation in the Retail/Postal Industry. Sustainability 2019, 11, 1749. [CrossRef]

18. Arvidsson, N.; Pazirandeh, A. An ex ante evaluation of mobile depots in cities: A sustainability perspective. Int. J. Sustain. Transp. 2017, 11, 623-632. [CrossRef]

19. Shostak, I.; Danova, M.; Kuznetsova, Y. Foresight-research for green IT engineering development. In Green IT Engineering: Concepts, Models, Complex Systems Architectures; Springer: Berlin/Heidelberg, Germany, 2017; pp. 21-41.

20. Fiorini, M.; Lin, J.C. Clean Mobility and Intelligent Transport Systems; IET: London, UK, 2015; Volume 1.

21. Strzelczak, S. Towards Ontology-Aided Manufacturing and Supply Chain Management-Insights from a Foresight Research. In IFIP International Conference on Advances in Production Management Systems; Springer: Berlin/Heidelberg, Germany, 2015; pp. 502-510.

22. Strzelczak, S. Production Internet-functional perspective. In IFIP International Conference on Advances in Production Management Systems; Springer: Berlin/Heidelberg, Germany, 2017; pp. 48-56.

23. Mazurkiewicz, A.; Poteralska, B. Methodology of Innovation Generation as an Instrument for Effective Management of Technological Innovations. In Proceedings of the 13th European Conference on Innovation and Entrepreneurship ECIE 2018; Academic Conferences and Publishing International Limited: Reading, UK, 2018; p. 467-XIX.

24. Kaivo-oja, J. Towards better participatory processes in technology foresight: How to link participatory foresight research to the methodological machinery of qualitative research and phenomenology? Futures 2017, 86, 94-106. [CrossRef]

25. Gudanowska, A.E. Technology mapping-proposal of a method of technology analysis in foresight studies. Verslas Teorija Ir Praktika 2016, 17, 243-250. [CrossRef]

26. Gudanowska, A.E. Technology mapping as a tool for technology analysis in foresight studies. In Proceedings of the 2014 IEEE International Technology Management Conference, Chicago, IL, USA, 12-15 June 2014; pp. 1-4.

27. Zolkifly, N.H.; Hussin, M.N. Digital Display of Car Showroom: Proposing an Emotional-Environmental Conceptual Model. Pertanika J. Soc. Sci. Hum. 2017, 25, 49-58.

28. Shcherbinin, D.; Prokhorov, S. The History of Science and Technology during the Transition to a Digital Economy. In Proceedings of the 2018 International Conference on Engineering Technologies and Computer Science (EnT), Moscow, Russia, 20-21 March 2018; pp. 8-10.

29. Leea, C.H.; Chen, C.H.; Leea, Y.C.; Xua, G.; Lla, F.; Zhao, X. Accelerating Retail-Innovation Design for Smart Services via Foresight Approach and Case-Based Design. Transdiscipl. Eng. A Paradig. Shift 2015, 5, 813-820.

30. Voronina, M.; Moroz, O. A substantiation of foresight research of development strategy of descriptive geometry, engineering geometry and computer graphics departments on the basis of industrial 4.0 ideology. Man India 2017, 97, 375-389.

31. Stahl, B.C. Virtual suicide and other ethical issues of emerging information technologies. Futures 2013, 50, 35-43. [CrossRef]

32. Cho, Y.; Kim, M. Entropy and gravity concepts as new methodological indexes to investigate technological convergence: Patent network-based approach. PLoS ONE 2014, 9, e98009. [CrossRef] [PubMed]

33. Aniskin, Y.; Moiseeva, N.; Rygalin, D.; Sedova, O. Technique of formation of the organizational system integrator for interaction of participants of the program for the development of the radio electronic industry. Int. J. Civ. Eng. Technol. 2017, 8, 906-915. 
34. Ramos, J.; Mansfield, T.; Priday, G. Foresight in a network era: Peer-producing alternative futures. J. Futures Stud. 2012, 17, 71-90.

35. Chan, L.; Daim, T. Exploring the impact of technology foresight studies on innovation: Case of BRIC countries. Futures 2012, 44, 618-630. [CrossRef]

36. Dobrzańska-Danikiewicz, A.; Dobrzański, L.; Mazurkiewicz, J.; Tomiczek, B. E-transfer of materials surface engineering e-foresight results. Arch. Mater. Sci. Eng. 2011, 52, 87-100.

37. Carsten Stahl, B. IT for a better future: How to integrate ethics, politics and innovation. J. Inf. Commun. Ethics Soc. 2011, 9, 140-156. [CrossRef]

38. Magruk, A. Innovative classification of technology foresight methods. Technol. Econ. Dev. Econ. 2011, 4, 700-715.

39. Dobrzańska-Danikiewicz, A.; Lukaszkowicz, K. Technology validation of coatings deposition onto the brass substrate. Arch. Mater. Sci. Eng. 2010, 46, 5-38.

40. Dobrzañska-Danikiewicz, A. E-foresight of materials surface engineering. Arch. Mater. Sci. 2010, 44, 44.

41. Yuan, B.J.; Hsieh, C.H.; Chang, C.C. National technology foresight research: A literature review from 1984 to 2005. Int. J. Foresight Innov. Policy 2010, 6, 5-35. [CrossRef]

42. Damrongchai, N.; Michelson, E.S. The future of science and technology and pro-poor applications. Foresight 2009, 11, 51-65. [CrossRef]

43. Santonen, T.; Kaivo-Oja, J.; Suomala, J. Brief Introduction to National Open Innovation System (NOIS) Paradigm: Integrating Online Social Networks and the Triple Helix Model. Available online: https:/ www. theseus.fi/handle/10024/116185?show=full (accessed on 8 January 2020).

44. Kononiuk, A.; Sacio-Szymańska, A.; Gáspár, J. How do companies envisage the future? Functional foresight approaches. Eng. Manag. Prod. Serv. 2017, 9, 21-33. [CrossRef]

45. Kováříková, L.; Grosová, S.; Baran, D. Critical factors impacting the adoption of foresight by companies. Foresight 2017, 19, 541-558. [CrossRef]

46. Dudin, M.N.; Protsenko, I.O.; Frolova, E.E.; Posokhov, S.P.; Voikova, N.A. Managing the Development of High-Tech Enterprises based on Foresighting. Acad. Strateg. Manag. J. 2017, 16-2, 1-9.

47. Rohrbeck, R.; Battistella, C.; Huizingh, E. Corporate foresight: An emerging field with a rich tradition. Technol. Forecast. Soc. Chang. 2015, 101,1-9. [CrossRef]

48. Kaivo-oja, J. Three theoretical approaches to pirate entrepreneurship: Towards future studies of pirate entrepreneurship. Int. J. Entrep. Small Bus. 2014, 22, 449-465.

49. Magruk, A. Concept of uncertainty in relation to the foresight research. Eng. Manag. Prod. Serv. 2017, 9, 46-55. [CrossRef]

50. Mendonça, S.; e Cunha, M.P.; Ruff, F.; Kaivo-oja, J. Venturing into the wilderness: Preparing for wild cards in the civil aircraft and asset-management industries. Long Range Plan. 2009, 42, 23-41. [CrossRef]

51. Iden, J.; Methlie, L.B.; Christensen, G.E. The nature of strategic foresight research: A systematic literature review. Technol. Forecast. Soc. Chang. 2017, 116, 87-97. [CrossRef]

52. Vervoort, J.; Gupta, A. Anticipating climate futures in a $1.5 \mathrm{C}$ era: The link between foresight and governance. Curr. Opin. Environ. Sustain. 2018, 31, 104-111. [CrossRef]

53. Lee, T.L.; Chuang, M.C. Foresight for public policy of solar energy industry in Taiwan: An application of delphi method and Q methodology. In Proceedings of the PICMET'12: Technology Management for Emerging Technologies, Vancouver, BC, Canada, 29 July-2 August 2012; pp. 60-67.

54. Amsteus, M. Managerial foresight: Measurement scale and estimation. Foresight 2011, 13, 58-76. [CrossRef]

55. Dobrzańska-Danikiewicz, A.; Tański, T.; Malara, S.; Domagała-Dubiel, J. Assessment of strategic development perspectives of laser treatment of casting magnesium alloys. Arch. Mater. Sci. Eng. 2010, 45, 5-39.

56. Amanatidou, E. "Joint foresight": Towards a mechanism for joint programming in Europe? Foresight 2008, 10, 103-117. [CrossRef]

57. Aniskin, Y.; Moiseeva, N.; Rygalin, D.; Sedova, O. Formation of modules of the mechanism of managing innovative activity on the basis of the system integrator. Int. J. Econ. Res. 2017, 14, 469-479.

58. Ejdys, J.; Szpilko, D. Problems of the strategic tourism management in the regions of Poland. Actual Probl. Econ. 2013, 146, 284-294. 
59. Jari, K.O.; Theresa, L. Knowledge Management and Triangulation Logic in the Foresight Research and Analyses in Business Process Management. In International Conference on Knowledge Management in Organizations; Springer: Berlin/Heidelberg, Germany, 2017; pp. 228-238.

60. Spickermann, A.; Zimmermann, M.; Heiko, A. Surface-and deep-level diversity in panel selection-Exploring diversity effects on response behaviour in foresight. Technol. Forecast. Soc. Chang. 2014, 85, 105-120. [CrossRef]

61. Birko, S.; Dove, E.S.; Özdemir, V. Evaluation of nine consensus indices in Delphi foresight research and their dependency on Delphi survey characteristics: A simulation study and debate on Delphi design and interpretation. PLoS ONE 2015, 10, e0135162. [CrossRef]

62. Paananen, A.; Mäkinen, S.J. Bibliometrics-based foresight on renewable energy production. Foresight 2013, 15, 465-476. [CrossRef]

63. Pysar, N.; Dergachova, V.; Kyvliuk, O.; Svyrydenko, D. Strategies for development of Ukrainian energy market under conditions of geopolitical challenges. Sci. Bull. Natl. Min. Univ. 2018, 148-154. [CrossRef]

64. Mikołajewicz-WoźNiak, A.; Scheibe, A. Virtual currency schemes-The future of financial services. Foresight 2015, 17, 365-377. [CrossRef]

65. Danko, T.; Kalinina, I.; Maslennikov, V.; Kiselev, V.; Sekerin, V.; Gorokhova, A. Foresight in management as a tool for the design transformation of marketing management of the potentials of small and medium-sized businesses. Int. J. Civ. Eng. Technol. 2018, 9, 1105-1113.

66. Malanowski, N.; Zweck, A. Bridging the gap between foresight and market research: Integrating methods to assess the economic potential of nanotechnology. Technol. Forecast. Soc. Chang. 2007, 74, 1805-1822. [CrossRef]

67. Erik Karlsen, J.; Øverland, E.F.; Karlsen, H. Sociological contributions to futures' theory building. Foresight 2010, 12, 59-72. [CrossRef]

68. Hayward, P. Resolving the moral impediments to foresight action. Foresight 2003, 5, 4-10. [CrossRef]

69. Farrelly, L. Redefining, Reinventing and Realigning Design for Demographic Change. Archit. Des. 2014, 2, 8-13. [CrossRef]

70. Schartinger, D.; Wilhelmer, D.; Holste, D.; Kubeczko, K. Assessing immediate learning impacts of large foresight processes. Foresight 2012, 14, 41-55. [CrossRef]

71. Barker, K.E.; Cox, D.; Sveinsdottir, T. Foresight on the future of public research metrology in Europe. Foresight 2011, 13, 5-18. [CrossRef]

72. Su, H.N.; Lee, P.C. Mapping knowledge structure by keyword co-occurrence: A first look at journal papers in Technology Foresight. Scientometrics 2010, 85, 65-79. [CrossRef]

73. Nugroho, Y.; Saritas, O. Incorporating network perspectives in foresight: A methodological proposal. Foresight 2009, 11, 21-41. [CrossRef]

74. Lee, Y.Y.; Tsou, C.S.; Lin, H.C.; Ien, C.H.; Wu, Y.T. Global perspective of health related edible plants from the agricultural point of view. Asia Pac. J. Clin. Nutr. 2008, 17, 95-98.

75. Puga, A. A Latvian experience addressing issues of the foresight innovation. Int. J. Foresight Innov. Policy 2007, 3, 369-387. [CrossRef]

76. Popper, R. How are foresight methods selected? Foresight 2008, 10, 62-89. [CrossRef]

77. Rodrigue, J.P.; Comtois, C.; Slack, B. The Geography of Transport Systems; Routledge: Abingdon, UK, 2016.

78. United Nations. 2018 Revision of World Urbanization Prospects; United Nations: New York, NY, USA, 2018.

79. UN-Habitat. World Cities Report 2016. Urbanization and Development-Emerging Futures; Technical Report; UNHabitat: New York, NY, USA, 2016. .

80. Hammad, A.W.; Akbarnezhad, A.; Rey, D. Sustainable urban facility location: Minimising noise pollution and network congestion. Trans. Res. Part E Logist. Transp. Rev. 2017, 107, 38-59. [CrossRef]

81. Doherty, S.; Hoyle, S. Supply Chain Decarbonization: The Role of Logistics and Transport in Reducing Supply Chain Carbon Emissions; World Economic Forum: Geneva, Switzerland, 2009.

82. Behrends, S.; Lindholm, M.; Woxenius, J. The impact of urban freight transport: A definition of sustainability from an actor's perspective. Transp. Plan. Technol. 2008, 31, 693-713. [CrossRef]

83. Crainic, T.G.; Ricciardi, N.; Storchi, G. Advanced freight transportation systems for congested urban areas. Transp. Res. Part C Emerg. Technol. 2004, 12, 119-137. [CrossRef]

84. Kramers, A.; Höjer, M.; Lövehagen, N.; Wangel, J. Smart sustainable cities-Exploring ICT solutions for reduced energy use in cities. Environ. Model. Softw. 2014, 56, 52-62. [CrossRef] 
85. Desa, U. World Population Prospects: The 2015 Revision, Key Findings and Advance Tables; Population Division Working Paper no ESA/P/WP; United Nations Department of Economic and Social Affairs: New York, NY, USA, 2015; Volume 241.

86. United Nations. World population prospects: The 2015 revision. United Nations Econ. Soc. Aff. 2015, 33, 1-66.

87. Deutsche Post DHL Group. DHL Cubicycles City Hub Frankfurt 02. Available online: https://www.dpdhl. $\mathrm{com} / \mathrm{en} /$ media-relations/media-center/tv-footage/dhl-cubicycles-city-hub-frankfurt-02.html (accessed on 11 February 2019).

88. Workhorse Group. HorseFly UAV Delivery System. Available online: http://workhorse.com/aerospace (accessed on 7 June 2019).

89. Kikuta, J.; Ito, T.; Tomiyama, I.; Yamamoto, S.; Yamada, T. New Subway-Integrated City Logistics Szystem. Procedia-Soc. Behav. Sci. 2012, 39, 476-489. [CrossRef]

90. Schatzmann, J.; Schäfer, R.; Eichelbaum, F. Foresight 2.0-Definition, overview \& evaluation. Eur. J. Futures Res. 2013, 1, 15.

91. Conway, M. Foresight: An Introduction; Thinking Futures: Melbourne, Australia, 2015 .

92. Glenn, J.C. Introduction to the Futures Research Methodology Series; United Nations University: Washington, DC, USA, 1994.

93. Mozuni, M.; Jonas, W. A Morphological Analysis Tool for Complex Future-Oriented Scenario Researches. In Proceedings of the Relating Systems Thinking and Design Symposium (RSD), Toronto, ON, Canada, 13-15 October 2016.

94. Conway, M.; Voros, J. Foresight: Learning from the future. J. Inst. Res. 2003, 12, 1-15.

95. Velove Cororpation. The Armadillo. Available online: https://www.velove.se/electric-cargo-bike (accessed on 11 February 2019) .

96. Shen, J.; Qiu, F.; Li, W.; Feng, P. A New Urban Logistics Transport System Based on a Public Transit Service. In Proceedings of the 15th COTA International Conference of Transportation Professionals, Beijing, China, 24-27 July 2015 ; pp. 650-661.

97. Fatnassi, E.; Chaouachi, J.; Klibi, W. Planning and operating a shared goods and passengers on-demand rapid transit system for sustainable city-logistics. Transp. Res. Part B Methodol. 2015, 81, 440-460. [CrossRef]

98. Masson, R.; Trentini, A.; Lehuédé, F.; Malhéné, N.; Péton, O.; Tlahig, H. Optimization of a city logistics transportation system with mixed passengers and goods. EURO J. Transp. Logist. 2017, 6, 81-109. [CrossRef]

99. Zwicky, F. Discovery, Invention, Research through the Morphological Approach; Macmillan: New York, NY, USA, 1969.

100. Ritchey, T. General Morphological Analysis: A General Method for Non-Quantified Modeling. Available online: https: / / www.semanticscholar.org/paper/General-Morphological-Analysis-*-A-general-methodRitchey/1c508d794dc86083cededa5cfddd144404a8d42e (accessed on 8 January 2020).

101. Geels, F.W.; Schot, J. Typology of sociotechnical transition pathways. Res. Policy 2007, 36, 399-417. [CrossRef]

102. Geels, F.W. The multi-level perspective on sustainability transitions: Responses to seven criticisms. Environ. Innov. Soc. Transit. 2011, 1, 24-40. [CrossRef]

103. Brundtland, G.H.; Khalid, M.; Agnelli, S.; Al-Athel, S.; Chidzero, B. Our Common Future; Oxford University Press: New York, NY, USA, 1987; Volume 8, pp. 29-31.

(C) 2020 by the authors. Licensee MDPI, Basel, Switzerland. This article is an open access article distributed under the terms and conditions of the Creative Commons Attribution (CC BY) license (http://creativecommons.org/licenses/by/4.0/). 